DAVID LIPTON

Economic Adviser to Solidarity

JEFFREY SACHS

Harvard University and Economic Adviser to Solidarity

\title{
Creating a Market Economy in Eastern Europe: The Case of Poland
}

THE POLITICAL and intellectual leaders of Eastern Europe's revolution of 1989 describe their aim as a "return to Europe." Their overwhelming judgment is that the postwar division of Europe into East and West was artificially imposed by the Soviet Union, at enormous human and economic cost. They underscore the artificiality of the division by referring to their region as East Central Europe (or Middle Europe), rather than Eastern Europe, thereby stressing their countries' place in the mainstream of European history, politics, arts, and economy.

The policy dimension of the return to Europe is the creation of political and economic institutions in the style of Western Europe. ${ }^{1}$ In this spirit, these countries are directed toward the creation of multiparty parliamentary democracies and market economies with large private sectors. ${ }^{2}$

1. The degree of consensus in Eastern Europe in favor of establishing a Western-style market economy certainly exceeds the levels of consensus found in Latin America and other parts of the developing world. In many Latin American countries, such as Argentina, Brazil, and Peru, there are still fundamental battles (even violent war in the case of Peru) about the kind of society and economy to which the nation should aspire. Of course, as the abstract idea of a market economy is put into practice and the pressures of adjustment grow, we will find out whether today's consensus survives. We believe that it will, largely because of the overwhelming attraction of the Western European example.

2. Of course, even Western Europe offers a wide array of alternative economic models from which to choose, but in practical terms there is little reason yet for the Eastern European countries to choose among the variants of Western European political economy. Before such choices have to be made, Eastern Europe should work hard to create the common core of market institutions found in all of Western Europe: private ownership protected by a commercial law, a corporate structure for industry, an independent financial system, and so forth. 
With amazing rapidity, the postcommunist politicians of Poland, Czechoslovakia, and Hungary have dropped any support for an economic " third way" - that is, some form of market socialism-and seem intent on moving instead to a full-fledged market economy based on private property. ${ }^{3}$ So far in 1990, political majorities in East Germany and Hungary have strongly rejected political currents linked to a continuation of socialism. ${ }^{4}$

The intense desire to rejoin the economies of Western Europe reflects both an attraction to the obvious achievements of Western Europe and a revulsion against the failures under communism. The low per capita incomes in Eastern Europe do not fully explain the pervasive sense of frustration in the region. It is one thing to be poor, but it is quite another to have become impoverished needlessly as a result of the failure of the communist system. It is the sense of unnecessary decay, as much as the deprivation itself, that motivates the impulse toward change. ${ }^{5}$

The postcommunist democratic governments will begin, in 1990, a process of comprehensive change aimed at the creation of market economies. Each government will face questions about the content of

3. At the same time, the new governments have intensified their diplomatic contact with Western European governments, regional institutions, and the international financial institutions to press for a close political and economic relationship. Czechoslovakia, Hungary, Poland, and Yugoslavia have appealed for new, intensive relationships with the Council of Europe, the European Community, and the Organization for Economic Cooperation and Development. The voters in East Germany went further, putting their electoral support in the March 1990 election behind the alliance opting for the most rapid reunification with West Germany.

4. Even the social democratic parties, considered just six months ago to represent the likely dominant political force in democratic regimes, have fared very poorly.

5. Solidarity's leading political theorist, Adam Michnik, has raised the issue of why even committed communists have been ready to turn their backs on the old system. Michnik's answer is that the collapse of living standards has been universal, affecting even the highest levels of the party. He summarizes this collapse as the "Doctrine of the Radiators," recently described in a speech at the University of Michigan.

"Three years ago all of the heaters [radiators] stopped working," said Michnik. Shivering in his apartment he thought that at least the Party officials were warm in their dachas. Then he met the wife of the former Polish premier at a friend's wedding. She was shivering. "Why are you cold?" he asked. She said "My husband is sitting at home wearing the fur hat given to him by Kosygin." The country's heaters were on "a permanent strike."

(Reported in Michigan Alumnus, January-February 1990, pp. 11-12.) 
market reforms, the pace of change, the sequence of change, and the design of international assistance in support of comprehensive change.

The strategy for change must take into account the specific historical circumstances of Eastern Europe as of 1990. Lessons from other regions and other periods are vital to an understanding of the likely economic consequences of possible actions, but for important reasons, the Eastern Europe context suggests a special course of action. In particular, a rapid transition to a market economy, with a heavy emphasis on economic integration with Western Europe-through free trade, active participation of foreign firms in the domestic economy, and closer political tieswill permit the Eastern European economies to overcome some of the thorniest problems of transition, both economic and political. ${ }^{6}$

To demonstrate this point, we will focus most of our discussion on Poland. The case of Poland is particularly instructive, not only because Poland is Eastern Europe's largest economy and most populous nation, but also because it is the first country to embark on a program of fundamental market reform under a noncommunist government. In September 1989, the Solidarity-led government of Prime Minister Tadeusz Mazowiecki came into office. On January 1, 1990, the government introduced a program of radical reform, designed by the economic team headed by Deputy Prime Minister Leszek Balcerowicz. The aim was to end Poland's hyperinflation and create the legal, institutional, and economic basis for a market economy. Though the program is only three months old, and it is therefore far too early to make any definitive judgments, early lessons from Poland are relevant for the other countries in the region.

In our analysis of Eastern Europe's transition to a market economy, we proceed in two parts. First, we summarize the prevailing economic and political conditions in Eastern Europe, which constitute the starting point for the transition to a market economy. Following Janos Kornai, we focus at length on the key role of shortages in the socialist economies and the implications of shortages for the transition strategy. ${ }^{7} \mathrm{We}$ also

6. Many of our conclusions concerning the need for a rapid and dramatic liberalization of the economy run parallel to those of Janos Kornai in his recently published strategy for economic transition in Hungary, The Road to a Free Economy. We have benefited enormously from detailed discussions with Professor Kornai.

7. See Kornai $(1980,1982,1986,1989,1990)$. 
outline our ideas about the basic strategy for a package of comprehensive reforms. Next, we narrow our focus to Poland, describing the conditions of the Polish economy, the strategy of reform that was adopted in Poland, the early results of the transition program, and the remaining agenda. We conclude with a brief discussion of the implications of the Polish case for the rest of Eastern Europe.

\section{Current Conditions in Eastern Europe}

Even with a consensus on the ultimate aims of reform, the tactical difficulties of creating a market economy are profound. Fundamental social, political, and economic changes must be carried out in the context of a deep and worsening economic crisis, inexperience in managing a market economy, fragile political institutions, the residual pressures of the communist power structure throughout society, the reemergence of historical enmities, and often very deep ethnic fissures. Moreover, the rapidly worsening economic crisis in the Soviet Union is producing an economic fallout in Council for Mutual Economic Assistance (CMEA) trade, and the risks of further instability in the Soviet Union hang like a pall over the region.

Because the political and economic conditions in the various countries differ markedly, the prospects for success differ as well. The prospects appear to be brightest in the most westward countries: East Germany (where the process will occur as part of reunification), Poland, Czechoslovakia, Hungary, and Yugoslavia. In Bulgaria and Romania, the conditions are considerably less favorable, both economically and politically. And despite Gorbachev's strong orientation toward Western Europe, the Soviet Union remains a case by itself, where it is difficult to find a national consensus on almost any matter, including a return to Europe.

\section{The Tyranny of Misleading Data}

Western economists, accustomed to Western standards of analysis, sometimes take Eastern European data at face value. The data, however, can be misleading for several reasons.

First, under the communist regimes, data have simply been faked in 
some cases, and collected on a very inadequate conceptual base in other cases. ${ }^{8}$ Real growth, for example, has been routinely overstated and inflation routinely understated in the data of Eastern Europe and the Soviet Union. Second, and most emphatically, in a shortage economyin which goods are not available at official prices-measures of real living standards (such as the wage deflated by the price index) are likely to contain a serious upward bias. In a market economy, a fall in real wages usually means a drop in living standards. But in a shortage economy, a fall in real wages can simply mean the elimination of queues, and therefore a rise in living standards.

Third, almost all analysts of the socialist economies recognize the extreme bias toward heavy industry, much of which produces goods used by other heavy industry but without benefits-either current or in the future-for consumption. This output is given an important weight in the production and GNP accounts, but it is of little true economic value. A Polish journalist recently put it well:

For the entire period of real socialism, investments were poured into a closed production circle that offered no profit: coal was necessary to produce electricity; electricity was necessary to produce steel; and steel was necessary to mine coal. All that produced a statistical growth in national income, a growth which, as we now see, actually meant a decline in national wealth. Let us keep in mind that the prices for everything were taken out of thin air. ${ }^{9}$

It is bad enough that these data problems pose a serious barrier to analysis. What is worse is that the data can provoke unwarranted pressures on policymakers. In the course of stabilization, for example, declines in measured real wages that will in fact vastly overstate the actual economic losses can nonetheless still generate strong political demands for government-mandated wage increases that could undermine the stabilization program itself.

With these data problems in mind, let us outline the main constraints on economic reform that face every government in the region. We

8. As Fallenbuchl (1989) describes, the following conceptual problems routinely lead to an overestimation of the rate of growth of net material product (a measure of the valueadded in production): double counting of inputs, inadequate depreciation allowances, inclusion of wasted materials, and, most important, an inadequate account of rising prices in the deflation of nominal magnitudes. For further discussion of data inadequacies, see Fallenbuchl (1985); Alton (1989); and Fink and Havlik (1989).

9. Ernest Skalski, “The Idiot's Economy," Gazeta International '90, week 10, 1990, p. 6. 
mention three categories: the Stalinist legacy, the economic crisis as of 1990, and the political context, including the international political and economic environment.

\section{The Stalinist Legacy}

The countries in Eastern Europe have a socialist ownership structure. Industrial production is typically 90 percent or more state owned; the service sector is also heavily state owned, though an unknown level of activity takes place in the grey or black market. ${ }^{10}$ Agriculture is generally state owned and controlled, except in Poland, where farmers retained their private land after World War II, though under highly restrictive and repressive conditions. ${ }^{11}$

The role of central planning as of 1990 differs considerably among countries. ${ }^{12}$ A summary statistic is the share of goods subject to central allocation by the central planning organs. By this measure, central planning remained in place until this year in Bulgaria, Czechoslovakia, East Germany, and Romania. Central allocation has been substantially phased out in Hungary and was progressively reduced in scope in Poland during the 1980s. In these latter economies, some portions of the economy, such as energy and trade with the Soviet Union, remained under central allocation until recently.

As Kornai has stressed, the shrinkage of the sphere of central planning in Hungary and Poland and the growing autonomy of enterprises did not mean the emergence of normal competitive market relations. ${ }^{13}$ Rather,

10. In the case of Poland, 71 percent of Polish workers are employed in the socialized sector (which includes state-owned enterprises and cooperatives). Most workers outside the socialized sector are employed in the predominantly private agricultural sector. Even more striking, 88 percent of the measured net material product in industry (including construction) and 86 percent of industrial employment is in socialized enterprises. (Of course, these statistics do not purport to measure black market economic activity.)

11. In Poland private farms account for 77 percent of total arable land and 80 percent of output. Nonetheless, the private farm sector was greatly circumscribed, as all of its inputs came from state enterprises and all its outputs had to be sold to the state. There were also restrictions on sales of land, which prevented a rationalization of farm sizes following prewar land reforms, and left the average farm a minuscule-and consequently inefficient-five hectares in size. See Balcerowicz $(1989$, p. 43) for land ownership data. Output figure comes from Rocznik Statystyczny.

12. For a comparative discussion of the state of reforms up to 1988 in the various countries, see Vacic (1989).

13. See Kornai (1986). 
under the process of communist-led reform in Hungary and Poland, central planning was replaced in part by market-type controls but also by a burgeoning of ad hoc negotiations between the enterprise and the financial authorities. While in a nominal sense enterprises were guided by prices, interest rates, and tax rates, rather than material allocations, in practice the prices, interest rates, and taxes have all been the subject of continual negotiation.

State enterprises, whether in Eastern Europe or elsewhere, almost inevitably create financial problems in two main areas of decisionmaking: wages (where they are prone to pay excessive wages out of the income stream that would otherwise accrue to the Treasury) and investment (where the manager has a craving for investment spending, because he stands to gain from control over a larger firm, but bears little or no cost if the investments fail). Even in Western Europe the state sector has run into repeated financial difficulties, and in Latin America the state sector has contributed significantly to the genesis of the debt crisis. But the situation in Eastern Europe is even more grave, since the state sector is not disciplined by being part of a larger market economy. To the ext nint that state enterprises have been decontrolled, but without introdu....g real market competition at the same time, the result has been a worsening of financial indiscipline of the firm and, eventually, of the macroeconomy. ${ }^{14}$

The state enterprise system does not rely on capital markets to allocate credit. Investment spending is typically negotiated between enterprises, the relevant government ministries, and the central planning commission. Once approved, investments are paid for by various reserve funds set aside by an enterprise, centrally allocated investment funds from the national budget, and loans from the central bank. None of these funding sources requires an adequate assessment of investment prospects.

The countries of Eastern Europe differ in the extent to which the private sector has been permitted to operate. It has been highly restricted in Bulgaria, Czechoslovakia, Romania, and Yugoslavia. A very small private service sector survived the socialization process in East Germany. A somewhat larger private sector has been allowed to operate under the reforms in Hungary and Poland. But even in these last cases, 
the private firms have been heavily restricted by administrative barriers, punitive tax laws, shortages of inputs, and unavailability of foreign exchange and credit, the allocation of which has been almost entirely directed to the state sector.

All the countries suffer from heavily distorted relative prices. Energy and household necessities (mainly food and rent) are heavily subsidized. The exchange rate is overvalued, in the sense that foreign exchange is rationed at the official price (both for current and capital transactions), so that the black market exchange rate is heavily depreciated relative to the official rate. Therefore, while import prices measured at the official exchange rate are cheap, most imported goods are severely rationed in supply (or simply not available), so that the effective price facing end users is extremely high.

On a sectoral level, the industrial structure in every country is strongly skewed toward heavy industry and capital goods and away from light industry, services, and consumer goods. This emphasis mainly reflects two factors: first, the obsessive growth orientation of the Stalinist model and, second, trade patterns instituted by the Soviet Union, which has induced the Eastern European countries to develop large industries to process Soviet raw materials and then reexport them to the Soviet Union in semifinished or finished form.

In Poland, for example, in 1987 the industrial and construction sectors produced 52 percent of GDP, compared with just 29 percent to 38 percent in Greece, Portugal, and Spain. By contrast, the growth of the service sector in Poland has been severely stunted by the focus on industry. In the same year the service sector in Poland employed 35 percent of the labor force, far less than in Greece, Spain, or Portugal (see table 1).

The organization of industry is designed to facilitate top-down planning, rather than market competition, with a heavy orientation toward large firms integrated both horizontally and vertically. There is a virtual absence of small to medium-sized firms, with employment between 50 and 100 , the kind of firm that plays such a vital role in growth in the Western industrialized economies. ${ }^{15}$ Part of this centralization results from large-scale production units, and part from the tendency to group separate factories in a particular sector together in a small number of

15. For a comparison of the size of establishments in socialist countries and capitalist countries, see Ehrlich (1985). 
Table 1. Real GDP and Employment by Sector, Poland and Selected Market Economies, 1980-87

Percent

\begin{tabular}{|c|c|c|c|c|c|c|}
\hline \multirow{2}{*}{$\begin{array}{l}\text { Sector and } \\
\text { country }\end{array}$} & \multicolumn{2}{|c|}{$\begin{array}{l}\text { Share in } \\
\text { total GDP }\end{array}$} & \multirow{2}{*}{$\begin{array}{c}\text { Average } \\
\text { annual } \\
\text { change in } \\
\text { sector GDP, } \\
1980-87\end{array}$} & \multicolumn{2}{|c|}{$\begin{array}{c}\text { Share in total } \\
\text { employment }\end{array}$} & \multirow{2}{*}{$\begin{array}{c}\text { Average } \\
\text { annual change } \\
\text { in sector } \\
\text { employment, } \\
1980-87\end{array}$} \\
\hline & 1980 & 1987 & & 1980 & 1987 & \\
\hline \multicolumn{7}{|l|}{ Industry ${ }^{\mathrm{b}}$} \\
\hline Poland & 42.6 & 41.7 & 0.4 & 30.1 & 28.5 & -0.9 \\
\hline Portugal & 31.4 & 30.6 & 1.6 & 27.1 & 26.5 & 0.4 \\
\hline Spain & 29.7 & 29.1 & 2.0 & 27.1 & 24.2 & -1.8 \\
\hline Greece & 26.1 & 25.1 & 2.3 & $20.7^{\mathrm{c}}$ & 21.5 & 1.0 \\
\hline \multicolumn{7}{|l|}{ Agriculture } \\
\hline Poland & 10.7 & 12.1 & 2.5 & 30.4 & 29.1 & -0.8 \\
\hline Portugal & 7.0 & 7.8 & 3.7 & 27.3 & 21.9 & -2.3 \\
\hline Spain & 6.9 & 6.3 & 0.8 & 19.2 & 15.1 & -3.6 \\
\hline Greece & 14.5 & 12.9 & -0.5 & $30.7^{\mathrm{c}}$ & 27.0 & -1.8 \\
\hline \multicolumn{7}{|l|}{ Construction } \\
\hline Poland & 12.6 & 10.5 & -1.9 & 7.7 & 7.8 & 0.0 \\
\hline Portugal & 6.1 & 5.5 & 0.5 & 9.5 & 9.3 & 0.4 \\
\hline Spain & 8.3 & 8.2 & 2.0 & 9.0 & 8.2 & -1.6 \\
\hline Greece & 6.3 & 4.7 & -3.3 & $8.3^{\mathrm{c}}$ & 6.4 & -4.0 \\
\hline \multicolumn{7}{|l|}{ Other sectors } \\
\hline Poland & 34.1 & 35.7 & 1.4 & 31.8 & 34.6 & 1.1 \\
\hline Portugal & 55.6 & 56.1 & 2.1 & 36.1 & 42.3 & 3.1 \\
\hline Spain & 55.1 & 56.4 & 2.6 & 44.7 & 52.5 & 2.2 \\
\hline Greece & 53.1 & 57.3 & 2.4 & $40.4^{c}$ & 45.0 & 2.2 \\
\hline
\end{tabular}

Sources: Rocznik Statystyczny (various years); OECD National Accounts, 1989; and OECD Labor Force Statistics, 1989. GDP calculations used GDP at factor price before adjusted to market price.

a. Greece, billions of drachmae in 1970 prices; Spain, billions of pesetas in 1980 prices; Portugal, billions of escudos in 1987 prices.

b. Includes mining, manufacturing, electricity, gas, water.

c. The employment figures for Greece are from 1981.

enterprises. The anticompetitive nature of the industrial structure is often exacerbated by the presence of enterprise associations that tie together firms at the industry level and act as cartels.

Consider again the case of Poland. The average state enterprise in Polish industry (excluding the so-called cooperative sector, which represents 13 percent of employment in the state sector) has 1,132 employees, typically in multiplant operations. The average number of employees per plant (again excluding the cooperative sector) is 378 (see table 2), compared with about 80 workers per plant in a sample of Western economies. The 115 largest enterprises, each with more than 5,000 
Table 2. The Distribution of Employment in Industry by Size of Establishment, Poland, 1937 and 1986, and Selected Market Economies

\begin{tabular}{|c|c|c|c|c|c|}
\hline \multirow[b]{2}{*}{ Country } & \multirow[b]{2}{*}{$\begin{array}{l}\text { Average } \\
\text { number of } \\
\text { workers per } \\
\text { establish- } \\
\text { ment }\end{array}$} & \multicolumn{4}{|c|}{ Workers per establishment } \\
\hline & & $\begin{array}{l}100 \text { or } \\
\text { fewer }\end{array}$ & $\begin{array}{c}101-500 \\
\text { (percentage }\end{array}$ & $\begin{array}{l}501-1,000 \\
\text { of all workers) }\end{array}$ & $\begin{array}{l}\text { Greater } \\
\text { than } \\
1,000\end{array}$ \\
\hline \multicolumn{6}{|l|}{ Poland } \\
\hline 1937 & 54 & $33^{\mathrm{a}}$ & 27 & $41^{\mathrm{b}}$ & n.a. \\
\hline $1986^{c}$ & 88 & 10 & 25 & 15 & $51^{d}$ \\
\hline State enterprises & 378 & 6 & 21 & 16 & $58^{\mathrm{e}}$ \\
\hline Cooperatives & 30 & 42 & 54 & 4 & 1 \\
\hline \multicolumn{6}{|l|}{ Sample of } \\
\hline Western economies ${ }^{f}$ & 80 & $35^{g}$ & 33 & 13 & 19 \\
\hline South Korea & n.a. & $33^{h}$ & & $67^{i}$ & \\
\hline \multicolumn{6}{|c|}{$\begin{array}{l}\text { Source: Data on Poland from Rocznik Statystyczny Przemyslu; data on sample of Western economies in } 1970 \text { from } \\
\text { Ehrlich (1985); data on South Korea in } 1982 \text { from World Bank (1989a). } \\
\text { n.a. Not available. } \\
\text { a. Includes employees in establishments of betweeen } 6 \text { and } 100 \text { employees. } \\
\text { b. Includes all employees in establishments with more than } 501 \text { employees. } \\
\text { c. Socialized sector. Employees in the private sector work in establishments with an average employment of } 2 \\
\text { workers. } \\
\text { d. Seventeen percent of all workers are in establishments with employment greater than } 5,000 \text {. } \\
\text { e. Nineteen percent of all workers are in establishments with employment greater than } 5,000 \text {. } \\
\text { f. Austria, Belgium, France, Italy, Japan, and Sweden. Percentage of workers employed in total manufacturing } \\
\text { excluding mining. } \\
\text { g. Includes employees in establishments of between } 10 \text { and } 100 \text { employees. } \\
\text { h. Includes employees in establishments of between } 4 \text { and } 99 \text { workers. } \\
\text { i. Includes all employees in establishments with employment greater than } 100 \text {. Twelve percent of employees are } \\
\text { in establishments with employment of } 101-200 ; 11 \text { percent are in establishments with employment of } 201-300 \text {; and } \\
44 \text { percent are in establishments with employment greater than } 300 \text {. }\end{array}$} \\
\hline
\end{tabular}

employees, account for more than one fifth of industrial employment and production. ${ }^{16}$ At the other end of the spectrum, only 982 enterprises in all of socialized industry in Poland have fewer than 100 employees. In Korea, where small and medium-sized enterprises have provided much of the impetus for growth and economic development, 33 percent of the labor force is employed in establishments with fewer than 100 workers. This contrasts with only 10 percent in the Polish state sector.

The socialist economies also lack adequate procedures for the entry and exit of enterprises. ${ }^{17}$ Enterprises are typically "founded" by ministries or local authorities, which at the same time arrange for the funding to begin operations. Absent such sponsorship, there is little chance that state enterprise activity can spring up to meet even the most obvious

16. See Rocznik Statystyczny Przemyslu (1989, p. 5).

17. See Balcerowicz (1989). 
economic needs. On the side of exit, bankruptcy and liquidation of state enterprise activity has been virtually unknown. In fact, the absence of markets and meaningful relative prices in the economy means that it is difficult, if not impossible, to distinguish between enterprises that should and should not survive.

All countries of Eastern Europe suffer from chronic excess demand, though to varying degrees. The extent of shortages at official prices has been very high in Bulgaria, Poland, and Romania, and less severe in Czechoslovakia, Hungary, and Yugoslavia. In the former countries, the supply of basic consumer goods (such as food) has been erratic and often formally rationed. Active black markets exist in which goods are available at a multiple of the official price. In Czechoslovakia, Hungary, and Yugoslavia, markets for basic consumer goods have generally cleared (though quality is often low and variety is limited), while shortages remain acute for housing, telephones, automobiles, and other types of consumer durables.

At the enterprise level, excess demand is manifested in chronic shortages of basic inputs at official prices. There are informal supply networks through which state enterprises cope in part with the chronic supply shortages. In Hungary and Poland, where small-scale private firms have been allowed to operate, the private sector firms are generally cut out from these informal supply networks, and therefore face extreme shortages and the need to bribe individuals in state-owned enterprises to obtain even a haphazard supply of inputs.

Another coping mechanism of all enterprises has been an autarkic production strategy in which the firm eschews specialization, at great cost to efficiency, in order to produce all the necessary components for the production process. It is more or less the opposite of Japan's just-intime (kanban) production organization, in which large firms rely on small, highly specialized firms to provide inputs on a carefully timed, highly reliable basis. In Eastern Europe, there are almost no small independent firms servicing large enterprises. All work is done inhouse. ${ }^{18}$

18. The results are sometimes bizarre. During 1976, when food shortages were particularly severe, the industrial enterprises were instructed that they would be permitted to raise their own farm animals to feed their work forces. More generally, firms are integrated throughout the entire production process. A shoe company makes its own cardboard boxes for the shoes; an electronics firm makes its own metal castings, and so forth. 
The origins of excess demand lie deep within the system and include: the planners' drive toward rapid growth through heavy investment; the soft budget constraint of enterprises engaged in constant negotiation with the financial authorities; the planners' fear of unemployment; and the communist regime's lack of legitimacy to impose strong austerity measures with public support and its unwillingness or inability to do so by brute force. ${ }^{19}$

\section{The Economic Crisis as of 1990}

The nature and timing of reforms will be dictated not only by the Stalinist legacy, but also by the immediate crisis facing the new governments. In all of Eastern Europe, economic performance has been weak in the $1980 \mathrm{~s}$, but the economic conditions have been especially bad in some countries.

In Poland, an open hyperinflation exploded in the fall of 1989, at the time of the change of power from communist rule to the Solidarity-led government. In Hungary, a deepening foreign debt crisis in the later half of the 1980s and the resultant tight fiscal and monetary policies have led to falling real consumption and rising inflation (on the order of 30-40 percent a year). In Romania, under a brutal schedule of debt repayments imposed by Ceausescu himself, living standards sank to the lowest levels in the region, with reports of widespread hunger and malnutrition. In Yugoslavia, a decade of high inflation and a heavy foreign debt burden caused a slide into an open hyperinflation in the fall of 1989.

In Czechoslovakia and East Germany, the immediate conditions appear to be somewhat less acute, though the situation in East Germany reportedly deteriorated after the large-scale exodus of workers in 1989. Reliable information is lacking on Bulgaria, though the financial conditions are apparently deteriorating seriously. One sign of deepening crisis is the recent unilateral suspension of debt servicing, announced at the end of March 1990. According to available information, Bulgaria had been engaged in a rapid debt buildup in the past five years, which presumably has cushioned a crisis that will now be faced.

19. See Grosfeld (1987), Kornai (1980, 1989), and Winiecki (1986b). Soft budget constraints refer to the cheap credit, subsidies, tax breaks, and the like that have cushioned enterprises from the rigors of real competition and have led to imprudent investment. 


\section{The Political Context}

The collapse of communist one-party rule was the sine qua non for an effective transition to a market economy. If one proposition has been tested by history, it is that the communist parties of Eastern Europe would not lead a process of radical reform sufficiently deep to create a real market economy. There were too many barriers: the ideology of state ownership; the power structure of the party, based heavily on stateenterprise managers and bureaucrats loath to allow real competition to the state enterprises; the communist leaderships' lack of legitimacy among the public, making it impossible to impose the short-run costs of deep economic restructuring; and the low regard in the West for the communist governments, making it impossible for them to mobilize the international financial support vital for the economic transition.

Thus, the emergence of noncommunist rule has been a fundamental watershed for real reform in Eastern Europe. But, at the same time, the emergence of noncommunist governments in the region not only does not erase all existing political difficulties, but actually introduces new ones. The economic strategy must take cognizance of the new political context, which, in our view, argues overwhelmingly for a very rapid, straightforward, and sharp program of economic reform.

The first point is the Latin American lesson of the 1980s, that a fragile democratic opening combined with a deep economic crisis is a fertile brew for populist politics. Only decisive actions by a reformist government can keep these populist pressures in check. In most countries, stabilization by itself will require a sharp cutback in budget subsidies and a rise in unemployment. The restructuring of industry will also impose costs on particular groups. The urgent need to address the deteriorating infrastructure (including the environment) may also require a reduction in current consumption. ${ }^{20}$

These conditions will produce ample opportunities for politicians who promise illusory low-cost paths to reform. In the short term, populist pressures will lead to opposition to cuts in subsidies and to calls for

20. To some extent, cuts in military spending and investment in heavy industry, combined with new external financing from abroad, can reduce the need for large cuts in current consumption. 
"reactivation" of the economy through wage increases and demand expansion. In the longer term, populist politicians will find support among workers in declining industries, who will press for protection, subsidies, and other steps to halt the necessary industrial restructuring. The risks are compounded because both electorates and government officials will be highly inexperienced in the process of real economic reform. There is little doubt that one dubious scheme after another will be proposed to try to circumvent the difficult processes of structural change.

Governments in the region may also be stymied by the likely reintroduction of prewar electoral rules based on proportional representation. Voting based on proportional representation tends to produce weak multiparty coalition governments that have a particularly difficult time reducing an inherited budget deficit. ${ }^{21}$ The prewar history of the region amply demonstrates this proposition. ${ }^{22}$

Another profound political difficulty relates to the bureaucracy. The new governments of Eastern Europe are inheriting bureaucracies created and appointed by the communist party. The structure and personnel in these bureaucracies will change only gradually over time. There are tens, if not hundreds, of thousands of officials whose professional experience lies in a lifetime of bureaucratic planning of economic life, with close links to party-appointed managers in the state enterprises.

The bureaucracy provides an extraordinarily important practical argument for radical free market policies, even in circumstances where "market failures" exist and pure theory might suggest more nuanced policies. It is naive to think of the existing bureaucracy as equipped, professionally or temperamentally, to implement sophisticated policies based on Western-style theories of the welfare economics of the "secondbest." The bureaucracy cannot be relied upon for efficiency in regulating monopoly prices, promoting infant industries, or implementing industrial policy.

21. See Roubini and Sachs (1989) for an empirical demonstration of this proposition.

22. In prewar Poland, for example, the electoral system produced, between 1920 and 1926, a series of weak governments, all of which were unable to deal decisively with Poland's financial instability. In 1926, General Pilsudski imposed, through a coup d'état, a government that then ruled independently of the Parliament. 
Other deep political fissures are likely to reopen, after decades of dormancy. The prewar rural-urban economic battles in the region are already revving up in Poland, and will likely do so soon in Hungary. ${ }^{23}$ The nationalist and ethnic battles, within countries and between countries, are also reawakening at an alarming rate. One can mention the recent nationalist violence in Yugoslavia, between Serbs and Albanians; in Romania, between ethnic Hungarians and Romanians in Transylvania; in Bulgaria, against the Turkish minority. Even many Slovak leaders are agitating for a break with the Czechs, or at least for national autonomy within a Czecho-Slovak federation with a weak central government.

\section{Structural Aspects of the Shortage Economy}

Before turning to the strategies for reform, it is essential to focus on the role of repressed inflation in Eastern Europe. Repressed inflation is important for two reasons. First, it is a fundamental factor in many of the deepest economic problems of the Eastern European economies: chronic shortages, poor export performance, the weakness of private firms trying to compete with state firms, and even the widespread corruption of state managers. These problems often appear to be more intractable than they really are. A strong dose of macroeconomic austerity (tight monetary and fiscal policies) can substantially alleviate many problems that are misinterpreted as structural rather than monetary.

Second, as a result of repressed inflation, the measured effects of various reforms are likely to differ substantially from their real effects. For example, decreases in real wages may well coincide with increases in real living standards, and vice versa. Thus, policymakers must understand the ramifications of repressed inflation in order to interpret correctly the results of reform measures.

23. In Poland, farmers have apparently suffered a terms of trade loss as a result of the liberalization of prices. Input prices, such as fertilizer, feed grains, diesel fuel, and tractors, have risen more than output prices. As a result, rural political organizations, including Rural Solidarity, have sharply criticized parts of the economic reform program. According to polling data, the popularity of the program in the countryside is, as of March 1990, lower than it is in the urban areas. 


\section{A Model of Repressed Inflation}

Consider a very simple situation, to begin our account of repressed inflation. ${ }^{24}$ Suppose that there is a single good, with a fixed nominal price $P$, and a fixed output supply $S$. Suppose also that nominal demand is exogenously given at the level $Y$. (We discuss the determinants of $Y$ later.) If $Y$ is less than $P S$, then output will be demand determined, with output equal to $Y / P$. If $Y$ is greater than $P S$, there will be excess demand, and all of $S$ will be sold. We will define excess demand $(e x)$ on the official market directly as the proportion by which $Y$ exceeds $P S$. Thus,

$$
e x=(Y-P S) / Y .
$$

Let us assume the following simple rationing mechanism in the case that $e x>0$. A queuing time $q$ must be expended in order to purchase each unit of the good, where $q$ is endogenous. The queue is formed by arbitrageurs (variously known in Eastern Europe as "middlemen," "black-marketeers," "profiteers," "speculators," and private-sector "traders"), who buy the output at the official price $P$ and sell it at a "'grey" (legal) or "black" (illegal) market price $P_{b}$.

All individuals (including the arbitrageurs) have a simple utility function,

$$
U=C+w L,
$$

where $L$ is leisure, and $C$ is consumption of the good. We will aggregate over the population, and think of $U, C$, and $L$ as economywide variables. The variable $w$ represents the (fixed) marginal utility of leisure. The maximum amount of time for leisure is the total nonwork hours, $N$, which is equal to the difference between total hours $(T)$ and hours worked $(H)$. Because output, $S$, is assumed to be fixed, $H$ is also assumed to be fixed. Waiting in line reduces the leisure time available below its maximum value, $N$. Aggregate waiting time is $q S$. Thus, total leisure time is simply

$$
L=N-q S,
$$

or the amount of time not spent working or waiting.

24. An elegant and sophisticated multigood model of queuing and hoarding phenomena under excess demand has recently been put forward in Weitzman (1990). 
We find the black market price by assuming that the "waiting business" has free entry and therefore zero profits. One unit of waiting yields a nominal profit equal to

$$
\left(P_{b}-P\right) / q,
$$

and a real profit (in units of goods on the black market)

$$
\left(P_{b}-P\right) /\left(P_{b} q\right) \text {. }
$$

This must be equated with the utility loss, $w$, from an increased unit of waiting. Thus,

$$
P_{b} q w=P_{b}-P
$$

or, upon rearranging,

$$
P_{b}=P /(1-w q) .
$$

Monetary equilibrium is given by the condition $P_{b} S=Y$, so that aggregate demand equals the total value of purchases in the black market. Therefore,

$$
P S /(1-w q)=Y .
$$

Solving for $q$, we find:

$$
q=(Y-P S) /(w Y),
$$

or

$$
q=e x / w .
$$

Thus, the amount of waiting time is directly proportional to the percent of excess demand in the economy. The utility level is also easy to find. Since total waiting is $q S$, leisure is given by $N-q S$ (equation 3), which equals

$$
N-e x S / w .
$$

Thus, as defined in equation 2 and because the consumption of goods equals the supply of goods, utility can be described as

$$
U=S+w(N-e x S / w),
$$

which can be rewritten as

$$
U=S(1-e x)+w N .
$$


When $e x>0$, utility is a linearly declining function of excess demand. We have a situation described long ago by Anne Krueger as the cost of "rent-seeking" behavior. Excess demand is costly because it leads to activities that consume real resources. In the example here, the nominal excess demand is dissipated by waiting in lines, and overall utility is reduced accordingly. Consider the effects of changes in officially measured "real income," $Y / P$, on utility. When $Y / P$ is less than supply $S$, output is demand determined and there is no waiting. Utility is simply given by

$$
U=Y / P+w N
$$

When there is excess demand, then, as demonstrated in equation 4 ,

$$
U=S(1-e x)+w N .
$$

The relationship between "real income" and utility is shown in figure 1 . As long as the system is demand determined, increases in real income cause increases in utility. But when the system is characterized by excess demand, increases in real income lead to decreases in utility.

Official statistics on real wages and real incomes in the Eastern European countries do not adequately capture the shortage phenomena and are mostly based on official prices-without taking into account that goods are generally not available at these prices without considerable queuing or other expenses (bribes, side payments, black market activity). Starting from a situation of excess demand, economic stabilization and reform are likely to result in measured real income declines combined with utility increases, or at least decreases in utility that are much less than what is suggested by official data.

The complexity of accurate utility measurements when shortages are ended is suggested by a recent journalistic account from Warsaw, following the sharp rise in prices at the beginning of 1990: " "I cry when I pay for gas,' a prominent editor and friend confessed, 'but one of the worst miseries of my existence- the endless hunting and queuing for fuel-is over. When I first filled up hassle-free in January, I was euphoric." ", 25

25. Mariusz Ziomecki, "After Years of Communist Rule, Poland Discovers the Miracle of Capitalism," Detroit Free Press, March 27, 1990. 
Figure 1. Real Income and Utility

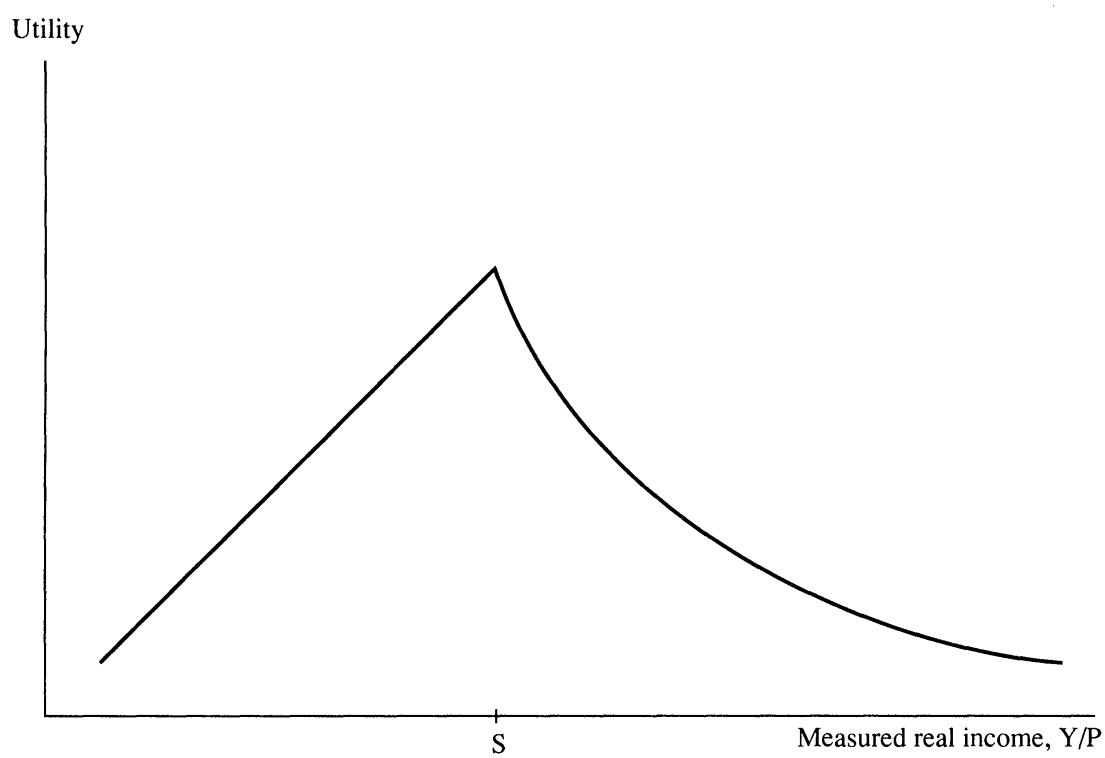

(Fixed supply)

A Polish journalist recently made the same point more abstractly:

No one likes it when his suffering is belittled, but we remember that real pay (what you can buy for a specific sum of money) is real only in a market economy where you can actually buy what you want. . . . Up to now, we have not been buying television sets because they were not available, whereas now, we are not buying them because they are too expensive. When we finally achieve satiation on the consumer goods market, real pay will begin to be what it should. ${ }^{26}$

The simple shortage model can be elaborated in several directions. First, excess demand also leads to hoarding. If each purchase is costly, it pays to bunch up on purchases, and to hold large inventories of goods. Not surprisingly, many households in Poland have kept several kilos of sugar on hand, and farmers have kept a shed full of coal or fertilizer. If these inventory hoards are costly (involving storage costs, depreciation, and opportunity costs), they constitute an additional burden of excess demand and reinforce the conclusion that measured real income and utility may move in opposite directions in a shortage economy.

26. Skalski, “The Idiot's Economy," p. 6. 
The shortage approach also highlights the possibility of corruption in the sale of goods. In the course of communist-led reforms in Hungary and Poland, private trading firms (cooperatives, as they are called in the Soviet Union) have been allowed. In these circumstances, state managers have taken the opportunity to open their own private firms, to which they sell the scarce state outputs at the official prices. The private firm then resells them at the black market prices. In this way, the managers are able to appropriate for their private benefit (and without queuing) the scarcity rents arising from the excess demand.

Chronic excess demand has a particularly systematic and harmful effect on the trading system. Suppose that the economy produces an exportable good, $S_{x}$, and an importable good, $S_{i}$. For the moment, assume that the supplies are fixed. Let the nominal exchange rate be fixed at the level $E$. Let us assume that exporters are required to remit their foreign exchange earnings at the official exchange rate, while importers buy foreign exchange from the central bank at the same exchange rate. We shall assume that the central bank has no stock of foreign exchange reserves. It simply sells what it takes in from the exporters. If there is an excess demand for imports, it rations the foreign exchange at the official price.

Suppose that the world price of the exportable good is 1 , and the world price of the importable good is $\boldsymbol{P}_{w_{i}}$. The official price of the exportable in the home market is $E$ (the world price times the exchange rate), and the official price of the importable is $E P_{w_{i}}$. Domestic output, at official prices, is

$$
E P_{w_{i}} S_{i}+E S_{x} .
$$

From equation 1 define excess demand as

$$
e x=\left(Y-E P_{w_{i}} S_{i}-E S_{x}\right) / Y .
$$

The export market clears domestically, in the sense that at the price $E$, we have $S_{x}>C_{x}$, where $C_{x}$ is the level of consumption of exportable goods. The gap $S_{x}-C_{x}$ equals $X$, the exports of good $x$. The import market, on the other hand, is of course characterized by the condition $C_{i}>S_{i}$, with the balance made up by imports, $I$. The balance of trade condition requires that $X=P_{w_{i}} I$ : imports are restricted by the amount of foreign currency earned from exports.

The import price for good $i$ is $E P_{w_{i}}$, for those importers lucky enough 
to get foreign exchange at the official exchange rate. But if there is an excess demand for $i$ at the official price, the importable good is rationed, and a black market will develop with price $P_{b_{i}}>E P_{w_{i}}$. Let $Y$ be the level of nominal demand, and let $a Y$ be expended on consumption of the $x$ good, and $(1-a) Y$ be expended on consumption of the $i$ good. Equilibria in the markets for the exportable and the importable are then given as follows:

$$
\begin{aligned}
E C_{x} & =a Y & & \text { Demand for exportables } \\
P_{b_{i}} C_{i} & =(1-a) Y & & \text { Demand for importables } \\
C_{x} & =S_{x}-X & & \text { Market clearing for } X \\
C_{i} & =S_{i}+I & & \text { Market clearing for } I \\
I & =X / P_{w_{i}} & & \text { Trade balance. }
\end{aligned}
$$

The model is readily solved. By simple substitution, we are able to find the following equation for the black market price relative to the official import price, assuming that ex $>0$ :

$$
P_{b_{i}} / E P_{w_{i}}=(1-a) /(1-e x-a) .
$$

Note what happens when excess demand increases from the point of balance, $e x=0$. As excess demand increases, the black market price of $i$ begins to rise relative to the landed price.

In this simple setup, we can interpret the spread between the black market price $P_{b_{i}}$ and the import price $E P_{w_{i}}$ as equal to the spread between the official exchange rate and the black market exchange rate. ${ }^{27}$ The term $P_{b_{i}} / P_{w_{i}}$ is a measure of the price that individuals would be willing to pay for foreign exchange assuming that they can use the foreign exchange to import freely the scarce commodity $i$.

Three types of inefficiencies are caused by excess demand in the open-economy context. First, to the extent that middlemen must queue to buy the rationed import goods, there is the rent-seeking loss noted earlier. Second, and new to this model, there is a consumption distortion caused by the gap between $P_{b_{i}}$ and $E P_{w_{i}}$. Because of the excess demand, the country consumes too much of its own exportable (which is in excess supply on the home market) and too little of the importable.

27. In practice, the black market exchange rate is usually a function of rationing on the capital account as well as the trade account, so that the black market exchange rate will not necessarily be equivalent to rationing in the goods market. 
The domestic excess demand reduces exports and thereby reduces imports, driving the domestic relative price of the importable above its world market relative price. With given levels of production $S_{i}$ and $S_{x}$, there is a welfare loss coming from the strangulation of exports and consequent shortage of imports. The result is as shown in figure 2. Production is at point $A$. Optimal consumption is at point $B$, where the slope of the line $A B$ reflects the international terms of trade between the importable good and the exportable good. With excess demand, actual consumption is at point $C$, where the slope of the price line facing the consumer, given by the slope of the tangent of the utility curve at $C$, is steeper (higher cost of $i$ ).

The third loss (not treated explicitly in the model) is the production distortion arising because firms will be induced to shift their production toward the import-competing sector and away from exports, to the extent that they respond to the rise in $P_{b_{i}}$. There is a constant refrain in Eastern Europe that exports are not competitive. Some of the export problems have to do with marketing and design, since firms have been separated from Western markets for so long. But a large part of the problem is the relative price problem. New export firms in the private sector will not arise if the price of exportables relative to importables has declined significantly under the pressure of excess demand.

Using this model, we can address one of the least understood issues in Eastern Europe: convertibility of the currency. If we restrict our attention to convertibility on the trade account, the model shows the basic conditions for convertibility, meaning the legal right of importers to purchase foreign exchange, without rationing, at the official exchange rate $E$. From this model, we see that the sine qua non of convertibility is the elimination of excess demand. When $e x$ is zero in the model, the market-clearing price for the import good is simply $P_{b_{i}}=E P_{w_{i}}$. There is no rationing of foreign exchange.

In this sense, convertibility is a macroeconomic (monetary) phenomenon, and not a structural problem related to the competitiveness of the export industry or the import-competing industry. Consider the expression for excess demand, as presented in equation 5 :

$$
e x=\left(Y-E P_{w_{i}} S_{i}-E S_{x}\right) / Y .
$$

Clearly, if $e x$ is positive, it can be reduced to zero by some combination of reducing $Y$ (budget cuts, tight money, and so forth) and devaluing $E$. 
Figure 2. Effect of Excess Demand on Trade

Exportable goods

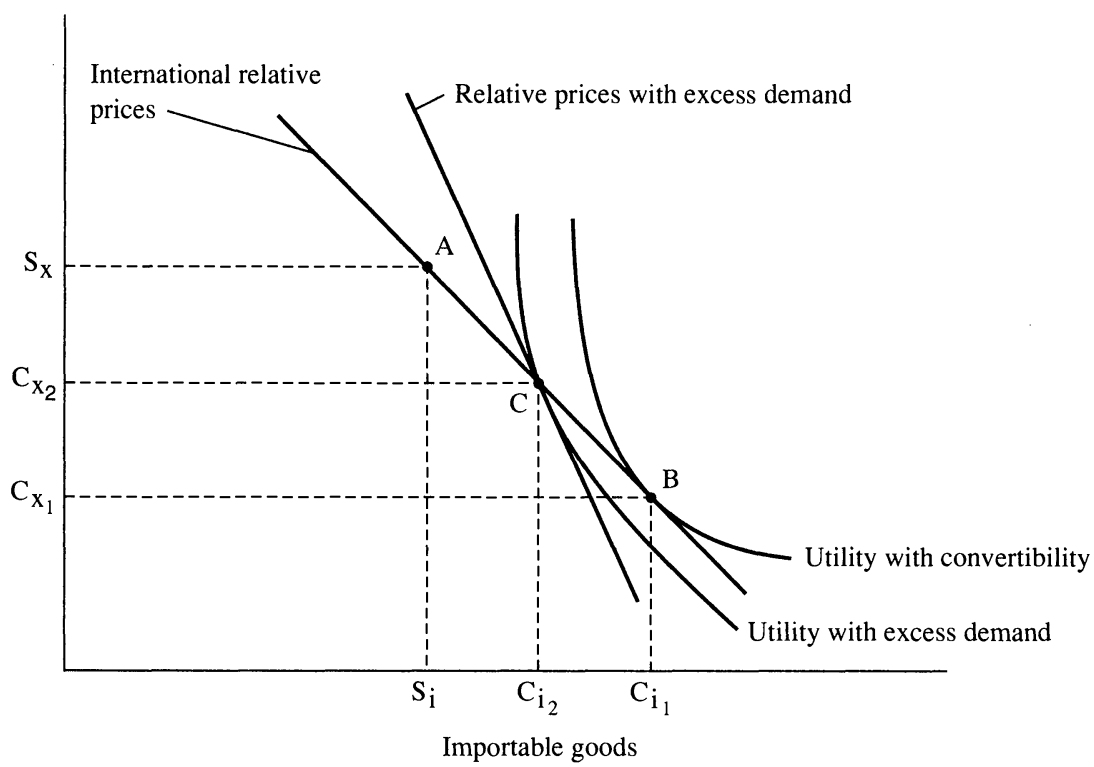

Another extension of our theoretical analysis of the shortage economy involves the question of inputs to the production process. In a generalized situation of excess demand, black market prices for inputs will tend to be above official input prices, often with devastating results. Exporters, for example, are heavily penalized if the price that they face for the export good is determined by the official exchange rate, while the input prices that they must pay are determined by excess demand. Suppose, for example, that the export production process uses imported inputs, as is normally the case. As $P_{b_{i}}$ rises relative to $E$, the exporter is squeezed, adding to the anti-export bias already observed.

Similarly, if downstream producers are subjected to domestic price controls, they will be squeezed by a rise in the black market price of inputs. In the final years of the communist regime in Poland, when private sector activity had been liberalized, the main complaint of private firms was that they could not obtain inputs from the state sector, except at highly inflated black market prices. Because the private firms were typically undertaking production contracts for the state sector at official 
prices, the firms found themselves strongly squeezed between rising input costs and administratively controlled output prices.

In this way, the shortage of inputs leads to a devastating disadvantage of private firms relative to state firms under the reform communism practiced in Hungary and Poland in the 1980s, and to a deep disadvantage of the cooperatives in the Soviet Union today. The private firms are cut off from the informal supply networks of the state enterprises. They can obtain goods only at the end of a long queue, typically with a bribe or on the black market, but at prices that are often prohibitive. An end to excess demand is key to the promotion of the private sector.

\section{Sources of Excess Demand}

The Eastern European economies have experienced chronic excess demand and shortages in the consumer goods markets for decades. Also, Hungary and Poland have suffered from high open inflation since the introduction of partial market reforms under the communist regimes. We should therefore consider the underlying driving forces of excess demand. In much of the Western press, the source of excess demand is assumed to be a "monetary overhang," a growing mountain of money in the face of administratively controlled prices. Such a view is much too narrow. The stock effect of high $M / P$-while real-is probably less important than various flow causes of high nominal aggregate demand.

These flow causes include: large budget deficits, as unpopular communist governments have resorted to large and often growing consumer subsidies; the soft budget constraint of firms, which leads firms to have an insatiable desire for credit to carry out investment projects of dubious value; the easy-money policies of central banks, in accommodating the insatiable demands for investment credits; the wage push pressures of workers at state firms, since these pressures are only weakly resisted by state managers (who are often themselves appointed by the workers councils); and the ideological commitment not just to "full employment" in the Western sense, but to zero unemployment as a socialist norm. ${ }^{28}$

The wealth effect of high $M / P$, by itself, is probably not decisive. Most saving by households is carried out as bank deposits in Eastern Europe, since other forms of financial and nonfinancial assets (for

28. See Rostowski (1989b) and Winiecki (1986b). 
example, equities, housing) are not available. Therefore, a ratio of money to income of 40 percent of GNP, for example, which seems very high by Western standards, is not so extraordinary when one considers that such bank savings represent the bulk of household nonhuman wealth and that much of the savings are in nonliquid savings accounts rather than currency. It is still true, however, that the excess demand pressures coming from high $M / P$ could be eased by introducing more attractive nonliquid monetary savings vehicles, with higher interest rates, to reduce holdings in highly liquid transactions balances.

A quantitative assessment of these alternative channels of excess demand remains to be made (and perhaps never can be, given the profound measurement problems involved in calculating excess demand). Our hunch, however, based on the studies of Kornai, Grosfeld, Winiecki, and others, as well as the experience of the Polish reforms, is that the insatiable investment demands, accommodated by state planners and by the central bank, have been decisive in creating chronic shortages.

\section{The Strategy of Transition}

Both the economic logic and the political situation argue for a rapid and comprehensive process of transition. History in Eastern Europe has taught the profound shortcomings of a piecemeal approach, and economic logic suggests the feasibility of a rapid transition. Moreover, the macroeconomic situation is deteriorating in many countries, and therefore requires urgent attention.

The transition process is a seamless web. Structural reforms cannot work without a working price system; a working price system cannot be put in place without ending excess demand and creating a convertible currency; and a credit squeeze and tight macroeconomic policy cannot be sustained unless prices are realistic, so that there is a rational basis for deciding which firms should be allowed to close. At the same time, for real structural adjustment to take place under the pressures of tight demand, the macroeconomic shock must be accompanied by other measures, including selling off state assets, freeing up the private sector, establishing procedures for bankruptcy, preparing a social safety net, and undertaking tax reform. Clearly, the reform process must be comprehensive. 
Politically, as well, there are powerful arguments for moving rapidly. Fragile governments facing a deep economic crisis are best able to carry out strong measures at the beginning of their tenure. For this reason, Machiavelli's famous advice is that a government should bring all of the bad news forward. ${ }^{29}$ Indeed, barring a political disaster emanating from the Soviet Union, probably the greatest political risk facing Eastern Europe is not a resurgence of communism, but the Argentine trap of political and social paralysis, in which coalitions of workers, managers, and bureaucrats in the declining sectors succeed in frustrating the needed adjustments.

For a government committed to a rapid and comprehensive program of adjustment, the first step must be to end excess demand. The shortage economy leads to rampant rent-seeking, queuing, hoarding, and antiexport bias, and an anti-private sector bias. Thus, excess demand must be eliminated first. Fiscal and monetary austerity in turn (and in conjunction with a currency devaluation) will permit the establishment of a stable convertible currency and thereby an end to the bureaucratic allocation of trade.

The second step of reform, which can be undertaken in parallel with the macroeconomic austerity program, should be to create market competition, based on the deregulation of prices, free trade, the full liberalization of the private sector, and the demonopolization of the state sector. Prices should be deregulated quickly, in parallel with the macroeconomic austerity program, because the proper relative prices are crucial for all the necessary resource reallocations. Price deregulation might lead to a one-time jump in prices, but not to an ongoing inflation, as long as macroeconomic policies remain tightly constrained.

Some economists have argued that price deregulation is too dangerous in the monopolistic conditions of the Eastern European economies. But such a view does not withstand closer scrutiny. Most sectors in most countries already have numerous firms and an even larger number of separate production plants that could become separate firms. Far more important, for most industrial sectors, free trade policies (based on currency convertibility, combined with a cut in trade quotas and tariffs)

29. And the former Bolivian Planning Minister, Gonzalo Sanchez de Losada, who brilliantly managed his country's stabilization and reform process during 1986-89, used to put it even more succinctly: "If you are going to chop off a cat's tail, do it in one stroke, not bit by bit." 
can provide an enormously effective mechanism for generating competition. Free trade instantly brings to bear on domestic firms the competition of the rest of the world. Even if the domestic production structure is highly concentrated when viewed internally, markets may be highly competitive if foreign producers are allowed to import without restriction.

For some nontradables industries, such as food processing in Poland, the private sector will be able to compete effectively with the state sector in a matter of weeks. But the private sector will emerge only if the proper price signals exist. Thus, a transitory period of monopolistic prices might well occur in some areas, but attempts to avoid this transitory period could lead to the failure to develop private sector competition in the longer term. In a small subset of industries, such as public utilities, telephones, and intercity rail transport, prices will inevitably continue to be set by the state, as in almost any Western European economy.

The third step of the reform process should be privatization, which, for reasons described later, is likely to take many years. In the meantime, state enterprises will have to be run on a tight leash-with wage controls and curbs on investment-to check their financially wasteful tendencies.

In addition to these tasks, several specific challenges must also be addressed. First, as unemployment will surely rise under the reform program, the governments will have to introduce a variety of labor market policies, including unemployment insurance, job retraining, and credit allocation to individuals who start small businesses. It should be remembered, however, that the unemployment starts from negligible levels, so that even steep rises in unemployment will tend to raise the unemployment rates to levels now existing in Western Europe. Second, Poland and Hungary, and possibly others, will have to renegotiate the terms on sovereign debt. Third, since the state sector will remain significant for several years, further efforts-in terms of rules for wage setting, investment, and restructuring-must be undertaken so that the economy does not fall back into financial crisis after an initial stabilization.

Skeptics often ask whether the austerity cum liberalization program outlined here can produce stable prices and economic growth. They observe that in Latin America similar programs have indeed ended inflation, but at the expense of hampered growth. In the case of Eastern Europe, however, one can identify the primary engine of growth in the 
coming years: economic integration with Western Europe.$^{30}$ If convertibility, free trade, macroeconomic stability, and liberalization of the private sector are all achieved, the power of natural market forces will reduce the gap between Poland's $\$ 1,100$ per capita income and Western Europe's per capita income more than 10 times that level.

With skilled workers in Eastern Europe now earning about $\$ 1$ an hour, the region will provide an enormous opportunity as a production site for European, Japanese, and U.S. firms selling mainly in the West European market. By April there were 1,200 applications for joint ventures pending with the Polish Foreign Investment Agency. Hundreds, if not thousands, of firms are already examining factory sites in Eastern Europe as potential locations for parts of their production process. They are finding a highly skilled labor force, with engineers, machine tool operators, foundry workers, and so forth, that will—under stable economic and political conditions-be able to integrate effectively into European-wide production operations.

To achieve the full fruits of trade liberalization, existing trade barriers (in both directions between East and West Europe) should be removed. The Eastern European countries must negotiate a new association status with the European Community to give them guaranteed future access to Western European markets. ${ }^{31}$ Existing restrictions of the Coordinating Committee for Multilateral Export Controls (COCOM), barring the export of high-technology goods to Eastern Europe, will have to be removed. Investment treaties, guaranteeing repatriation rights on foreign investment, must also be negotiated.

Much of the pessimism about growth in Eastern Europe results from the focus on the necessary decline of the region's heavy industrial sectors. More attention should be paid to the obvious and crucial sectors, particularly in services, house construction, and light industry, that will grow considerably. Intense shortages exist in these areas, and, even under the arduous business conditions of reform communism, the private

30. In Latin America, macroeconomic stability with outward orientation has in fact produced favorable growth results, especially compared with countries still mired in high inflation and protectionist policies. But many Latin American countries, unlike those in Eastern Europe, are predominantly dependent on volatile natural resource exports, and these countries have suffered serious terms of trade declines in the past decade.

31. In the longer term, the EC should be expanded to allow for the actual membership of the East European countries. 
sector has been staking out a foothold in these areas. Ample opportunities exist for rapid expansion in these areas.

\section{Creating the Market Economy in Poland}

As in other Eastern European countries, the growth of Poland's economy in the 1950 s and 1960 s created the impression that central planning could generate sustained economic growth. The well-known upward biases of the official growth statistics provide good reason to discount the high reported rates of growth during this period. Nonetheless it is clear that both industrial and agricultural production rose steadily. The growth of production in these sectors was based upon large-scale investment in heavy industry and the absorption of labor from the rural sector.

By the early 1970s, however, it became apparent that these sources of growth were being exhausted. In response, the government embarked on a program of modernization, based in large part on the importation of Western capital equipment and technology. Fed by these imports, real investment grew at an annual average of nearly 11 percent between 1970 and 1978 according to official statistics. As a result, industrial production showed a 9 percent annual average increase over the period.

Instead of reestablishing a foundation for sustained economic expansion, the modernization strategy led to a deep balance of payments crisis. Imports from the West in the 1970s were financed by Western credits. As a result, the current account of the balance of payments went sharply into deficit, peaking at nearly 10 percent of GDP in 1975. External debt, which had been negligible in 1970 , exceeded $\$ 26$ billion, or the equivalent of 40 percent of GDP, by the end of the decade. Finally, as the supply of foreign capital dried up, imports from the West had to be cut back sharply, with import volumes falling more than 50 percent between 1979 and 1982.

The balance of payments crisis exposed the incapacity of the Polish economic system to sustain growth. During the crisis years, 1979-82, which saw the birth of Solidarity, its clashes with the government, and the imposition of martial law, real investment was cut nearly in half and industrial production fell by one-third. In 1981, some 1,600 investment 
projects were stopped, and only later resumed at a slower pace. ${ }^{32}$ With this slowdown, it became impossible to maintain the standard of living that had been supported by borrowing. As a result of the harsh adjustment imposed in 1982 under the cover of martial law, real wages and per capita consumption fell sharply, to about 15 percent below the 1978 levels. Growth resumed at modest levels between 1983 and 1988, and according to official data the 1978 production and consumption levels were not restored until 1988, though it is likely that the 1978 living standard has in fact not been restored. ${ }^{33}$ See table 3 for the official growth statistics during 1970-89.

On balance, Poland's economic performance since the onset of the balance of payments crisis in 1979 has been dismal. Aggregate real net material product, which attempts to measure the value-added in the material or productive sphere, was the same in 1989 as in 1978. Zbigniew Fallenbuchl's analysis of official statistics from this period suggests that the actual performance was far worse than reported. ${ }^{34}$ Importantly, the price deflation techniques led to inadequate correction of nominal magnitudes for inflation as it accelerated in the 1980s.

More telling was that the socialized (or public) enterprises in the industrial sector, which formed the backbone of the economic system, were unable to generate any growth or vitality: value-added among these enterprises fell 3 percent and employment fell 14 percent between 1978 and 1988. At the same time, measures of the gross capital stock and the consumption of electricity (up 30 percent), coal (up 5 percent), lignite or brown coal (up 92 percent), and other raw materials by industry show substantial increases during the period. ${ }^{35}$ Clearly the economy has been under great strain in the effort to keep output from falling, an accomplishment that was possible only because of increases in the capital-output ratio and in the energy intensity of industry.

The stagnation of economic activity is seen vividly in Poland's failure to spur a vigorous growth in exports to service its debts. Poland's exports to the West increased only 19 percent from 1978 to 1989 , at a time that the real value of world trade expanded about 60 percent and

32. See Fallenbuchl (1989, p. 125).

33. For reviews of Poland's economic experience in the 1980s see Fallenbuchl (1989) and Kaminski (1989).

34. See Fallenbuchl $(1985,1989)$.

35. Rocznik Statystyczny (1989). 
Table 3. Output, Inflation, and Real Wages in Poland, 1970-89

Average annual percentage change

\begin{tabular}{ccccr}
\hline Year & $\begin{array}{c}\text { Net } \\
\text { material } \\
\text { product }\end{array}$ & $\begin{array}{c}\text { Consumer } \\
\text { prices }\end{array}$ & $\begin{array}{c}\text { Average } \\
\text { wages }\end{array}$ & $\begin{array}{c}\text { Real } \\
\text { wages }\end{array}$ \\
\hline $1970-78$ & 7.9 & 3.8 & 10.3 & 6.3 \\
$1979-81$ & -6.8 & 13.1 & 16.3 & 2.8 \\
1982 & -5.5 & 100.1 & 56.0 & -28.7 \\
1983 & 6.0 & 22.0 & 27.7 & 19.0 \\
1984 & 5.6 & 15.1 & 13.6 & -1.3 \\
1985 & 3.4 & 15.1 & 19.9 & 4.2 \\
1986 & 4.9 & 17.7 & 21.1 & 2.9 \\
1987 & 1.7 & 25.2 & 21.4 & -3.1 \\
1988 & 4.7 & 60.0 & 83.9 & 15.0 \\
1989 & $-1.0^{\mathrm{a}}$ & $257.1^{\mathrm{b}}$ & 298.6 & 11.6 \\
\hline
\end{tabular}

Source: All 1989 data are from Ministry of Finance; price and wage data for 1982-88 are from IMF, International Financial Statistics; NMP data for 1982-88 are from United Nations Economic Commission for Europe, Economic Survey of Europe (1988-89); 1970-81 data are from U.N., Economic Survey of Europe, various years.

a. Estimate.

b. Changes are calculated from annual averages. With the acceleration of inflation in 1989, the rate of price increase was much higher on the basis of an end-of-year comparison. Consumer prices rose 636 percent between December 1988 and December 1989.

exports of Western European countries rose more than 50 percent. Poland's response to its inability to export to the West during the period of martial law was to reorient trade toward the East. While this reorientation provided partial relief from the restraints on import growth, the deepening of ties with the East only delayed and impeded the needed modernization and restructuring of the economy. ${ }^{36}$

The result of Poland's poor production and trade performance was a failure to improve the standard of living. According to official data, real per capita consumption was only 4 percent higher in 1988 than 1978, compared with a rise of 21 percent in Western Europe. But the statistics clearly overstate Poland's growth. The official data capture neither the lack of availability of goods at administered prices nor other forms of

36. See Fallenbuchl (1989). The lack of dynamism in the export sector stemmed from the perverse industrial resource allocation in Poland's shortage economy and a chronically overvalued exchange rate. In the early 1980s Poland maintained a complex multiple currency system. Since 1982 there has been one official rate, which has been chronically overvalued. For example, the parallel rate averaged five times the official rate (with a range of three to ten times) between 1978 and 1988. The overvaluation policy was conceived both as an anti-inflation policy and a deliberate attempt to limit "excessive" profitability among major exporters. 
hidden inflation described by Fallenbuchl. All in all, it is clear that Poland fell further behind Western Europe during the decade.

What is difficult is to quantify the size of the gap with the West. The International Monetary Fund and the World Bank place per capita GDP in 1988 at about $\$ 1,800$, using the official national income account statistics and converting at the official exchange rate. ${ }^{37}$ Conversion at the more depreciated parallel exchange rate of that year (or at a weighted average) would produce a much lower figure. For 1990, the IMF is using a figure of about $\$ 1,100$ per capita. On this basis, Poland's standard of living is much closer to that of Latin America than to that of the lowerincome countries of Southern Europe. ${ }^{38}$

\section{Failures of Communist-Led Reforms of the 1980s}

After the onset of the balance of payments crisis, the government of Poland undertook two stages of partial reform, in 1981-82 and in 198788 , intended to decentralize economic decisionmaking. The government achieved a modest success in the areas of production and investment planning, wage setting, enterprise finance, and international trade. Many aspects of the decentralization have eased the process of transformation to a market economy in 1990. Nonetheless, the reforms failed to invigorate the economy, mainly because they failed to lead to the creation of real markets with real competition.

The attempts at decentralization touched many areas of economic activity, but focused on improving production and export performance in the enterprise sector. First, in 1982 most enterprises were released from mandatory participation in sectoral associations that had acted like

37. See World Bank (1989b).

38. These measures of per capita income are much lower than have been found in other studies. Based on production data (for example, tons of steel, inputs of energy), various studies have estimated per capita output in Poland in the range of $\$ 5,000-\$ 6,000$. See Alton (1989) for high-range estimates. It is clear, though, that the production data vastly overstate household living standards, in view of the high resource intensity of production, for example, very high energy inputs per unit of output, and the fact that so little output shows up as consumer goods.

Direct data on levels of consumption of consumer durables tend to support the lower numbers, or at least figures in between. In terms of people per telephone, or people per automobile, Poland's rank is between that of countries like Argentina, Mexico, South Africa, and Panama, which have per capita GDPs of $\$ 1,800$ to $\$ 3,000$, and that of countries like Greece, Ireland, Spain, or Portugal, which have per capita GDPs in the range of $\$ 4,000$ to $\$ 7,000$. See World Bank (1989b). 
cartels in their particular markets. As it turned out, many enterprises formed voluntary associations to retain informal linkages that guaranteed their market power.

Second, in an effort to reduce central control over the management of material balances in the economy, enterprises were progressively given greater autonomy over productive decisions. The central allocation of inputs was steadily reduced from 70 percent in 1982 to only about 10 percent last year. On the other hand, two special practices also introduced in 1982, "operational programs" and "government contracts," provided new forms of central coordination of productive activity and the allocation of inputs. Leszek Balcerowicz explains that in 1986, these mechanisms meant that the government was still involved in about 80 percent of the sales of producer goods. ${ }^{39}$

Third, centrally planned investment was gradually reduced, leaving enterprises responsible for more of the financing and execution of investment projects. Fourth, some producer prices were freed from administrative control. Instead, for a wide range of goods, prices were regulated on the basis of costs and subjected to government monitoring. For some goods, "contract" pricing was allowed, meaning, in principle, that prices were free to be set in the marketplace.

In the event, the system was changed frequently in the 1980s and remained complex throughout the period. On balance, the pricing system became more rather than less arbitrary and was increasingly subject to bureaucratic negotiation. Despite major adjustments to administered prices in 1982 and 1988 and the attempts to make price determination more flexible, there was no fundamental realignment of relative prices nor a sustained elimination of shortages.

Fifth, and more important, attempts were made to decentralize the wage-setting process and thereby increase efficiency in the use of labor by permitting enterprises to determine wages more freely. But the results were predictable: accelerating wage increases. The managers, intent on industrial peace, were content to concede to wage demands. ${ }^{40}$ Workers pushed for wage increases to capture the income flow that would

39. See Balcerowicz (1989, p. 44).

40. Indeed, under the reforms of the state enterprises, workers councils were given more control over managers, and hence over wage decisions. Managers were sometimes elected directly by workers councils. More generally, they had little incentive to oppose pressures for wage increases. 
otherwise accrue to the state, and the large and influential state enterprises could find cheap financing or subsidies to fund wage increases. In any event, the Polish economy was in a perpetual state of over-full employment and labor shortage, which kept up the wage pressures.

Sixth, efforts were made to improve the international trade and exchange system. Enterprises were given some latitude to conduct trade themselves, rather than relying exclusively on the foreign trade organizations, a few large state trading companies that had dominated international trade. Then in 1985 , the government decided to reduce the overvaluation of the zloty and began to depreciate the official exchange rate at a pace far more rapid than the rate of inflation. Ultimately, this policy failed to trigger a fundamental improvement in export performance. ${ }^{41}$ The parallel exchange rate remained a multiple of the official exchange rate throughout the period of real depreciation because of the general condition of shortage created by the macroeconomic imbalances in the economy. Currency convertibility was considered a far-distant goal even by ardent reformers and attempts to fine-tune the exchange system led to an increasingly complex and arbitrary multiple currency system.

An important goal of the decentralization effort was to make enterprises self-financing in order to instill financial discipline and, thereby, harden the soft budget constraint. Profitability was to become the key criterion according to which enterprises would be judged, and, accordingly, management was expected to seek efficiency and improve product quality. The banking system and the budget authorities were to judge enterprises according to their performance, ending the automatic accommodation of demands for subsidies, tax reliefs, and credits. Enterprises judged nonviable were to face bankruptcy.

In practice, little came of efforts to instill financial discipline among enterprises. Following the introduction of a bankruptcy law in 1983, only 11 state enterprises were liquidated. An initiative to enforce the bankruptcy procedures in 1988 led to the identification of 140 enterprises deemed candidates, but the decision to begin liquidation was taken in only 33 cases. In addition, attempts to wrest control over the appointment of enterprise management from the communist party were ineffective.

41. For a general discussion of the anti-export bias of the socialist economies, see Winiecki (1986a). 
Moreover, decentralization actually increased bureaucratic bargaining, as direct central control was replaced with a plethora of indirect policy instruments that came to be exercised with growing arbitrariness. Enterprises bargained for credits, subsidies, tax reliefs, and access to foreign exchange. The rules in each of these areas changed so frequently that in practice there were no rules.

Decentralization in the end turned out to be a poor substitute for the creation of real markets. Enterprises were neither privy to the information that markets might have provided, nor subjected to the discipline of market forces. The lack of provisions for free entry and exit, the shelter from competition from abroad, and the absence of capital market discipline on investment decisions and wage setting all contributed to the failure to invigorate the economy.

\section{The Emergence of Hyperinflation}

The final year of the communist system saw a complete collapse of financial control in the budget, the banking system, and the balance of payments (various data are shown in table 4). The setting for the collapse was the ongoing balance of payments crisis. While Poland repeatedly rescheduled a substantial portion of its debt service obligations, actual debt servicing remained large. With exports stagnant, the government had to continue to squeeze imports and hence living standards to produce the necessary trade surplus.

The government attempted a new austerity program in early 1988mainly involving cuts in subsidies and resulting in sharp increases in consumer prices-but because of a profound lack of popular support for the government, the policies were swamped by a tidal wave of subsequent wage demands. According to Ministry of Finance sources, the real wage in the socialized sector actually rose an average of 14 percent in 1988, though the government was trying to reduce the real wage. The only result of the price increase was to unleash a wage-price-exchange rate spiral: measured consumer price inflation accelerated sharply to 60 percent in 1988 and the zloty value of the dollar in the official exchange system rose 133 percent between the beginning of 1988 and February of 1989.

Three events in 1989 appear to have played key roles in pushing the spiral into a hyperinflation. First, in March 1989 households were given 
Table 4. Poland: Selected Indicators, January 1989-March 1990

\begin{tabular}{|c|c|c|c|c|c|c|c|}
\hline $\begin{array}{c}\text { Month } \\
\text { and } \\
\text { year }\end{array}$ & $\begin{array}{c}\text { Real } \\
\text { wage } \\
\text { (index, } \\
\text { January } \\
1989= \\
1.00 \text { ) }\end{array}$ & $\begin{array}{c}\text { Monthly } \\
\text { change } \\
\text { in real } \\
\text { wage } \\
\text { (percent) }\end{array}$ & $\begin{array}{l}\text { Monthly } \\
\text { rate of } \\
\text { inflation } \\
\text { (percent) }\end{array}$ & $\begin{array}{l}\text { Official } \\
\text { exchange } \\
\text { rate } \\
\text { (zlotys } \\
\text { per } \\
\text { dollar) }\end{array}$ & $\begin{array}{c}\text { Ratio of } \\
\text { parallel } \\
\text { to } \\
\text { official } \\
\text { exchange } \\
\text { rate }\end{array}$ & $\begin{array}{l}\text { Real } \\
\text { broad } \\
\text { money } \\
\text { (index, }^{\mathrm{a}} \\
1988: 4 \\
=100 \text { ) }\end{array}$ & $\begin{array}{c}\text { Deposits } \\
\text { denominated } \\
\text { in foreign } \\
\text { currency } \\
\text { (billions of } \\
\text { dollars) }\end{array}$ \\
\hline \multicolumn{8}{|l|}{1989} \\
\hline January & 1.00 & -40.1 & 11.0 & 506 & 6.7 & n.a. & n.a. \\
\hline February & 1.18 & 18.2 & 7.9 & 526 & 6.2 & n.a. & n.a. \\
\hline March & 1.46 & 24.0 & 8.1 & 566 & 5.3 & 88 & 5.3 \\
\hline April & 1.29 & -12.0 & 9.8 & 631 & 5.5 & n.a. & n.a. \\
\hline May & 1.15 & -10.9 & 7.2 & 746 & 5.3 & n.a. & n.a. \\
\hline June & 1.24 & 8.1 & 6.1 & 849 & 5.4 & 89 & 6.1 \\
\hline July & 1.19 & -4.1 & 9.5 & 836 & 6.8 & n.a. & n.a. \\
\hline August & 1.73 & 45.2 & 39.5 & 988 & 7.4 & n.a. & n.a. \\
\hline September & 1.30 & -24.5 & 34.4 & 1,340 & 7.1 & 57 & 7.0 \\
\hline October & 1.06 & -18.2 & 54.8 & 1,970 & 4.1 & n.a. & n.a. \\
\hline November & 1.08 & 1.9 & 22.4 & 3,077 & 2.2 & n.a. & n.a. \\
\hline December & 1.36 & 25.6 & 17.7 & 5,235 & 1.7 & 40 & 7.2 \\
\hline \multicolumn{8}{|l|}{1990} \\
\hline January & 0.77 & -43.2 & 78.6 & 9,500 & 1.0 & 32 & 6.3 \\
\hline February & 0.66 & -14.9 & $23.9^{\mathrm{b}}$ & 9,500 & 1.0 & 31 & 6.1 \\
\hline March & 0.69 & 4.3 & 4.7 & 9,500 & 1.0 & 36 & 6.0 \\
\hline
\end{tabular}

Sources: Wage, inflation, and monetary data from Ministry of Finance; official exchange rates from IMF, International Financial Statistics; the parallel exchange rate is from Wyzanski (1989).

n.a. Not available.

a. Includes only broad money denominated in zlotys.

b. The official inflation data compare the average price level for each month with the average price level in the previous month. Estimates of inflation during February (that is, comparing the price levels at the end of the month) show that inflation was about 5 percent. The difference derives from the fact that the price level was much higher at the end of January than on average in January, because of the corrective inflation.

legal access to foreign exchange in the parallel market, turning the black market white. This supported a flight from the currency. Second, as the result of the round table talks between Solidarity and the government, formal wage indexation was adopted in April 1989. The indexation was intended to guarantee that wages would rise no less than 80 percent of the increase in retail prices over the rest of the year. In practice, the adjustments guaranteed by the indexation scheme were in many cases added to other wage increases already achieved. As a result, the measured real wage in the socialized sector in August 1989 was 45 percent higher than one year earlier. Third, the last important reform carried out by the communist government was to free most retail food prices and some agricultural input prices from controls in August 1989 and sharply reduce the level of food subsidies. These measures led to an 
explosion of food prices (an increase of 180 percent in August according to the official statistics) and an intensification of the wage-price-exchange rate spiral.

\section{Poland's Reform Effort}

The Solidarity-led government took office on September 12, 1989, and immediately embraced as its principal economic goal the move to a market economy. The strategy chosen to bring about this transformation has been dubbed a "leap to the market," because it involved two radical steps, rapid stabilization and the immediate liberalization of prices and international trade and finance. Taken together, these steps were intended to end the financial chaos surrounding the hyperinflation and to introduce competition from abroad as quickly and widely as possible. The object of competition was the rapid emergence of markets for goods, labor, and capital, thereby creating an appropriate environment for the massive resource reallocation necessary for a fundamental transformation of the economy.

At the same time, the strategy included a host of legislative and executive initiatives aimed at wiping away the remnants of the previous economic system and building a legal and institutional foundation for a market economy. These initiatives included: privatization, to begin transforming the ownership structure of national assets; a competition program, to break up and prevent monopolies, remove restrictions to the entry of new enterprises, and introduce bankruptcy procedures suited to a corporate setting; banking system modernization, to increase the number and variety of financial institutions and improve the regulatory, accounting, and prudential environment; and tax reform, to reduce the present reliance on the distortionary turnover tax and introduce a broad-based value-added tax and a personal income tax. The time required to execute these initiatives will vary, and in some cases will take many years, but much of the necessary legislation has already been prepared and adopted.

\section{The Preparation}

While plans for stabilization and liberalization were being drawn up between September 1989 and January 1, 1990, several moves were made to prepare the ground for what was to come. First, a measure of budgetary 
control was regained, removing the fiscal pressure for money creation. ${ }^{42}$ Second, the wage indexation scheme was tightened, so that the indexation corrections could not be claimed on top of wage increases otherwise granted. With this change, real wages in the main industrial sectors fell 37 percent between August and November. Third, the National Bank of Poland (NBP) intensified its efforts to keep the growth of credit below the rate of inflation. In the last quarter of the year, broad money (M-2) denominated in zlotys fell 27 percent.

As a result of these measures, particularly the tightening of credit, the parallel exchange rate appreciated sharply from its low of around Zl 10,000 per dollar in September to about Z1 7,000 per dollar in November and early December. Over roughly the same period, the NBP

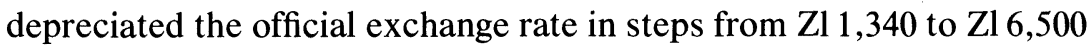
by the end of December. The aim was to allow traded goods prices to adjust substantially before attempting price and exchange rate stabilization. As a result, the exchange rate spread fell to 64 percent on average in December, the lowest spread in more than 15 years.

\section{Stabilization and Liberalization}

The stabilization and liberalization program began January 1, 1990. Stabilization was to be achieved by a set of five mutually reinforcing policies aimed at reducing aggregate demand and anchoring the price level. First, budget balance would be quickly restored by a sharp cut in subsidies and investment spending. Second, the growth of net domestic credit of the banking system would be tightly controlled, partly through a sharp increase in interest rates in the banking system. Third, the exchange rate would be devalued and made convertible, and then stabilized at the new depreciated rate. Fourth, the nominal wage growth would be limited through a tax-based policy designed to limit the rate of increase in the wage bills of state enterprises. Fifth, prices would be liberalized, except in certain regulated sectors (such as public utilities)

42. Shortly after assuming office, the government sent to the parliament a provisional budget for the remainder of the year, which was needed because the budgeted nominal spending limits for the year had been exceeded. Investment spending was cut back sharply. The liberalization of food prices in August and, then, the elimination of the remaining food subsidies in October slashed expenditures on food subsidies, which had been 5 percent of GDP in 1988. In addition, several import subsidies and selected agricultural subsidies were eliminated in October. 
where there would be a sharp, one-time adjustment. The liberalization would bring about a one-time corrective inflation that would correspond to a reduction in the real value of zloty-denominated money.

Thus, aggregate demand was to be reduced through several channels: a tight budget, a restrictive policy of new credit expansion by the central bank, a reduction in real money balances, and a reduction in the real wage.

On January 1, the official exchange rate was depreciated from Zl 6,500 per dollar to Z1 9,500 per dollar, and currency convertibility was established. The government replaced the existing system of multiple exchange rates with a single, fixed exchange rate for current account transactions. ${ }^{43}$ Exporters now surrender their foreign currency proceeds at a single uniform exchange rate, and importers have unrestricted access to foreign currency at the same official rate. ${ }^{44}$ While the government did not commit to maintain the nominal parity of $\mathrm{Zl} \mathrm{9,500} \mathrm{per} \mathrm{dollar,} \mathrm{the}$ NBP has kept the official exchange rate fixed throughout the first quarter of 1990.

Households that want to purchase dollars for non-trade-related reasons may do so in a parallel "kantor" market. Since the kantors (money exchange houses) may always sell dollars to the central bank at the official exchange rate, the value of the currency in the kantor market can never appreciate beyond the official exchange rate. The kantors may also be supplied with dollars at the official exchange rate on a discretionary basis. In practice, since January 1, the kantor exchange rate has been within a couple of percent of the official exchange rate of $\mathrm{Zl} \mathrm{9,500.}$

43. The system at the end of 1989 involved an overvalued official exchange rate accompanied by a variety of rationing devices. Exporters were required to remit part of their earnings at the official exchange rate, retaining the remainder in foreign exchange according to various "retention quota" rules. On the import side, some foreign exchange was administratively allocated, and some was sold to importers in a series of auctions.

44. Official foreign exchange is not provided freely for capital account transactions. The reason for distinguishing capital from current transactions upon the introduction of convertibility was concern on the part of the government and the NBP regarding the defensibility of a fixed parity, given the uncertainties surrounding the launching of the stabilization program. This concern stemmed from the fact that Poland's stock of liquid international reserves on January 1 totaled about the equivalent of one month's imports from the West. Accordingly, under the present system households are free to make foreign exchange transactions in the parallel market, but enterprises are prohibited from doing so, nor are they permitted to increase their holdings of foreign currency deposits. It is intended that macroeconomic policies will be managed so as to suppress the emergence of a substantial parallel market spread due to capital flows. Throughout the first quarter of 1990, there was no appreciable spread between the parallel and the official exchange rate. 
The stability of the official exchange rate and the lack of a parallel market spread has meant that, since the impact of the January 1 depreciation, the prices of traded goods have remained very stable in zloty terms. This effect on traded goods prices has made the exchange rate an effective nominal anchor.

The exchange rate depreciation was accompanied by a massive adjustment of prices brought about by price liberalization and huge adjustments of administered prices. Just before the January 1 target date, most of the remaining price controls on consumer and producer goods were removed, leaving only about 5 percent of consumer prices and 5 percent of producer prices subject to control. The bulk of the remaining controls cover goods and services commonly regulated in Western economies, such as public utility rates, public transportation fares, and goods produced in highly concentrated sectors, such as coal, where monopolistic practices might be expected.

Energy prices, which had fallen sharply in real terms over the course of 1989, shot up, with regulated coal and electricity prices rising between 300 percent and 600 percent and gasoline and other petroleum prices freed from price controls. Apparently the energy price increases were swiftly passed through to final goods prices of industrial goods, distribution charges, and retail prices.

The exchange rate depreciation, price liberalization, and the sharp increases in administered prices produced a burst of corrective inflation. Consumer prices in January were measured to be 78 percent higher on average than in December, according to the official consumer price index. Ministry of Finance officials estimate that prices rose 112 percent from the end of December to the end of January. The bulk of the increase clearly took place within the first two weeks of the month. According to a weekly price survey conducted by the Ministry of Finance, which produced a comprehensive index beginning in the third week of January, consumer prices rose only 1.3 percent and 0.5 percent in the last two weeks of January. Inflation remained low in February and March. The Ministry of Finance survey shows that inflation in February was about 5 percent on a point-to-point basis, and the official statistics report that March inflation was also about 5 percent. ${ }^{45}$

45. Because prices rose sharply in January, but were leveling off in February, the average month-over-month inflation rate for February was 23 percent, while the endpointto-endpoint inflation rate for February was only 5 percent. 
The government also adopted a taxed-based policy aimed at preventing the corrective inflation from being incorporated into wages. Upon the expiration of the wage indexation law at the end of 1989, a wage norm was established that allowed enterprise wage bills to rise by 30 percent of the increase in retail prices in January, and 20 percent thereafter. Increases in the wage bill above this norm were subjected to tax rates of 200 percent and more for larger increases. In this decision, the government compromised between two approaches most commonly taken in stabilization efforts: a complete wage liberalization and a wage freeze.

Full wage liberalization was supported by some Polish economists on the grounds that a flexible adjustment of wages was needed to facilitate real economic transformation. While viewed sympathetically, this argument was rejected for two reasons. First, with subsidies being so sharply cut, there was a danger that the rise in prices would set off a destructive wage-price spiral. ${ }^{46}$ Second, because the economy is dominated by state enterprises, there is, in wage setting, an inherent lack of market discipline that in a normal economy is provided by the owners of the firm. Poland's recent experience had confirmed that state enterprise managers had little taste or power to resist the wage demands of the work force, even when the higher wages sharply reduced the profits accruing to the Treasury.

It was recognized that the wage policy would bring about a substantial decline in the measured real wage as subsidies and shortages were eliminated. But it was also recognized that the real wage decline would greatly overstate the actual decline in real living standards, because the price adjustments were occurring in a shortage economy. As our theoretical analysis has shown, it was even possible that real wages would fall while utility levels would rise. ${ }^{47}$ It was indeed widely agreed that the

46. In other words, since the economy was being hit by a (necessary and self-imposed) supply shock, it was important that nominal wages not be raised in an attempt to keep up with price increases.

47. We noted earlier that with shortages, official prices do not capture the effective prices (including queuing) paid by consumers. But there is another reason why the reduction in the real wage overstates the fall in living standards, one that is common to all high inflations. During a high inflation, the "inflation tax" reduces the real value of nominal money balances held by households, with the result that the real wage level overstates the real consumption level that it can support.

Suppose that a worker is paid 100 at the beginning of the month, and that the price level 
sharp real wage increases in 1988 and 1989 had failed to improve living standards, because they fueled shortages and inflation. In the event, measured real wages in the five main industrial sectors during March 1990 were 36 percent, excluding bonus payments (and 14 percent including bonus payments), lower than in November of 1989.48

One indication that living standards have probably not deteriorated as sharply as measured is the increasingly positive response to questions about material well-being in recent opinion polls. Last fall, 84 percent of respondents to the official, government opinion poll described their material well-being as somewhat bad to very bad (see table 5). The overwhelming negative response was a realistic appraisal of the abysmal state of the economy and presumably also a reflection of the hyperinflation that was breaking out. As fundamental improvements in living standards will come only in the course of the economic transformation, a large proportion of the population continues to report that their material well-being is poor. Nonetheless, there is a significant and growing positive response: the fraction of respondents who feel that their material well-being is at least not bad rose from 13 percent last fall, to 20 percent in January and 27 percent in March. Similar, but more dramatic, improvements have taken place in perceptions about the state of the economy as a whole.

At the same time that the government adopted its wage program, the growth of net domestic assets of the banking system was brought under control. Legislation was approved by the parliament to prohibit the NBP from extending credit to the national budget, aside from a small and limited amount of seasonal credit. Accordingly, the 1990 budget calls for the reduction of the deficit to the equivalent of 1 percent of GDP (from more than 8 percent in 1989) to be funded by non-central bank

at the beginning of the month is 1.0 . His real wage will be measured as 100 . Now suppose that he keeps his wage in cash throughout the month, and spends the 100 in the middle of the month. If prices remain constant, real consumption will equal 100. If prices double, however, real consumption will equal 50 . The real wage index will overstate the real consumption level.

When hyperinflation is ended, and the inflation tax disappears, it is therefore likely that the measured decline in the real wage will overstate the resulting fall in real consumption supported by the new real wage.

48. The appropriate comparison is with November, rather than December, when a special indexation adjustment was paid in anticipation of the price increases set for January 1990. 
Table 5. Poland: Economic Opinion Polls

Percent

\begin{tabular}{lccccc}
\hline \multicolumn{1}{c}{ Item } & $\begin{array}{c}\text { September } \\
1989\end{array}$ & $\begin{array}{c}\text { November } \\
1989\end{array}$ & $\begin{array}{c}\text { January } \\
1990\end{array}$ & $\begin{array}{c}\text { February } \\
1990\end{array}$ & $\begin{array}{c}\text { March } \\
1990\end{array}$ \\
\hline Material well-being & & & & & \\
Very good & 0.3 & 1.4 & 0.6 & 1.2 & 1.4 \\
Good & 1.9 & 3.5 & 3.0 & 2.9 & 5.1 \\
Not good, not bad & 10.5 & 16.2 & 15.9 & 16.8 & 20.3 \\
Somewhat bad & 19.7 & 27.0 & 29.7 & 29.2 & 32.6 \\
Bad & 32.8 & 28.3 & 29.8 & 28.7 & 25.4 \\
Very bad & 31.8 & 19.6 & 17.4 & 18.6 & 10.6 \\
Undecided & 2.9 & 3.9 & 3.6 & 2.5 & 4.6 \\
Overall economic situation & & & & & \\
Very good & 0.6 & 1.1 & 0.6 & 1.8 & 3.2 \\
Good & 0.4 & 2.7 & 1.6 & 3.7 & 10.6 \\
Not good, not bad & 4.8 & 9.6 & 9.8 & 15.9 & 25.4 \\
Somewhat bad & 17.2 & 34.1 & 29.1 & 34.0 & 30.2 \\
Bad & 32.8 & 30.2 & 32.0 & 27.6 & 18.3 \\
Very bad & 42.9 & 20.8 & 24.8 & 14.7 & 7.8 \\
Undecided & 1.3 & 1.4 & 2.0 & 2.4 & 4.5 \\
\hline
\end{tabular}

Source: Centrum Badania Opinii Spolecznej (Central Opinion Polling Service) (April 1990).

finance. Government subsidies will fall by about 8 percent of GDP, owing to the elimination of food and agricultural input subsidies, a deep cut in coal subsidies, and the reduction of real wages paid by industrial enterprises. In addition, the real wage decline in the budgetary sphere will drive down the ratio of government wage payments in relation to GDP.

The spending cuts are partly offset by increases in spending for new social safety net programs and other forms of social insurance, so total expenditure (including subsidies) is budgeted to fall by 4 percentage points of GDP. Revenues, on the other hand, should return to the proportion of GDP achieved in 1988 owing to the effect of lower inflation in generating higher real tax revenues (the so-called Tanzi effect) and the elimination of various forms of tax relief available in 1989. As it has turned out, the national budget is apparently in surplus in the first quarter of 1990. A large deficit early in the year had been expected, both because of seasonal factors and the impact of the stabilization measures.

The NBP has maintained a tight rein on credit expansion to the rest of the economy, a policy enforced by a combination of very high interest 
rates and closer supervision of the credit activities of the major commercial banks. The basic rate for loans from the NBP to the state commercial banks was, on a monthly basis, 36 percent in January, 20 percent in February, and 10 percent in March. These extraordinarily high monthly rates have exceeded the inflation rate by a large margin since mid-January and, in light of the fixed exchange rate parity, have given savers a large premium over returns on foreign currency assets. With the demand for credit on the part of enterprises sharply reduced by the high interest rates, the stock of net domestic assets in the banking system fell more than 50 percent in real terms between January 1 and mid-March.

The measures aimed at rapid stabilization are also part of the plan to create real markets in the Polish economy as rapidly as possible. The most important example is that the establishment of currency convertibility and the restoration of macroeconomic balance have made possible a sweeping liberalization of the international trade regime. Trade liberalization was intended to bring competition to the economy instantly and provide a counterweight to the extreme concentration in industry. Quite simply, free trade was viewed as the quickest and most effective anti-monopoly policy. Of course in the longer run, free trade would be an essential ingredient of the process of integration with the West. It would bring Western technology to Poland and ensure a steady growth of demand.

To strengthen the move to free trade, quantitative restrictions on imports from the West were eliminated, and, with the exception of temporary surcharges on luxury consumer goods and a few exemptions, a uniform tariff of 20 percent was adopted. Similarly the export regime was liberalized with the elimination of most quantitative restrictions and decreases in export taxes. Moreover, the rules restricting enterprises from participating in international commerce were liberalized, loosening the tight grip of the foreign trade organizations in this area.

Poland's reform program has been supported by two important forms of financial assistance from the West. First and foremost has been balance of payments support. The NBP's meager reserve of liquid foreign exchange balances has been substantially bolstered by a $\$ 700$ million standby arrangement with the IMF, a $\$ 215$ million Bank for International Settlements bridge loan to the first drawing of the standby, and a $\$ 1$ billion stabilization fund created by industrial country govern- 
ments. The availability of this balance of payments support made it possible for the Polish authorities to consider the introduction of a convertible and stable exchange rate. The increased backing for the zloty made the defense of the zloty more credible.

A second form of Western financial assistance is temporary cash-flow relief from external indebtedness. Poland's external debt in convertible currencies stood at $\$ 40.3$ billion at the end of 1989 , of which $\$ 27.7$ billion was owed to Paris Club creditors, $\$ 9.2$ billion to commercial bank creditors, and $\$ 2.1$ billion to CMEA countries. The interest falling due on this debt in 1990 is about $\$ 3.6$ billion, which would consume more than 40 percent of the proceeds of Poland's exports of goods and services to the West. To increase the chance that Poland's economy can successfully be stabilized, it was vitally important that debt service payments be minimized in 1990. The Paris Club creditors responded to Poland's immediate debt servicing crisis in February, agreeing to reschedule virtually all of the principal and interest falling due through March 1991. Meetings with commercial bank creditors have not yet resulted in any formal agreement on cash flow relief in 1990, but in the interim, Poland has not been making interest payments to commercial bank creditors on medium- and long-term credits.

\section{The Rapid Shift from a Shortage to a Surplus Economy}

As of April 1990, several initial goals of the stabilization phase of Poland's program appear to be within reach. The corrective inflation has subsided, and aggregate demand has been sharply reduced. With tight demand and a currency devaluation, Poland has been able to introduce a convertible currency, a liberal trade regime, the free determination of most goods prices, and a reasonable set of relative prices including those for energy and food.

The most immediate consequence of the new environment has been the sharp reduction of shortages in the economy. Apart from those goods still subjected to administered prices, such as medicines, queues have all but disappeared. Meat is freely available at all times in the official shops. The notorious gas station lines are gone. Foreign consumer goods, such as bananas and strawberries, and consumer electronic products are now widely available. Durable goods, many of which used to require months or years for delivery, can now be purchased in department stores. 
According to unpublished survey evidence of enterprises, industry can now find materials and spare parts that were in perpetual scarcity under the previous system. Agricultural inputs are available throughout the countryside. While it is difficult to measure the value of time no longer spent waiting in queues and searching for goods, as well as the savings from no longer opting for substitutes when the desired commodity is unavailable, it is clear from survey data that Poland's economy has reaped a substantial gain.

The most profound effect of the "demand barrier," combined with the cutoff of cheap credits, is the pressure that it places on state enterprises to adjust in order to survive. Accustomed to a state distribution network that accepted all factory output, regardless of quantity or quality, enterprise managers now lack buyers for their goods. An extensive series of visits to state enterprises by experienced Western management consultants has shown that the managers of Polish industry are struggling to adapt to the new environment. ${ }^{49}$

In response, most managers have begun a two-pronged strategy that includes reevaluating their production processes and, in the face of undesired inventory accumulation, looking for new markets at home and abroad. As an important example, enterprises have begun to economize on energy use, with many plants introducing night shifts to take advantage of cheaper electricity. Obviously, the pressure on enterprises stemming from tight credit is not a long-run substitute for profit maximization under private ownership and cannot be expected to lead to wholly efficient operations. On the other hand, the absence of easy credit and ready subsidies and tax relief in the new, restrictive financial environment has forced enterprises to weigh cost considerations as never before.

The combination of high interest rates and an accumulation of inventories in January led to a wave of forced two-week vacations for employees. Subsequently, workers have begun to lose jobs. Official data

49. See McDonald (1990). For more anecdotal evidence, consider the following report from the Wall Street Journal (Barry Newman, "Poles Find the Freeing of the Economy Lifts Supplies-and Prices," February 21, 1990, p. 1): "Poland's debt-panicked managers haven't all sunk into fantasy. They are scrambling. They are selling straight from their warehouses, driving into cities to sell from the backs of trucks, running auctions, dumping inventory for scrap. And at the Tomex woolen mill in Tomaszow, between Katowice and Warsaw, Wieslaw Mokrowiecki is working in the dark. 'I am saving electricity,' the manager says." 
show unemployment rising from less than 50,000 in January to about 266,000 by end-March (the equivalent of about 1.5 percent of the labor force of 18 million). In fact, only 115,000 of this number were unemployed as a result of layoffs; the remainder was accounted for by voluntary job leavers and new entrants to the labor force. More important, indications from industry are that many enterprises view much of their labor force as redundant and that unemployment will continue to rise sharply in the months to come. The Minister of Labor has predicted unemployment of 500,000 workers, while other observers have suggested figures of $1,000,000$ or higher.

The slackening of the labor situation is also affecting the behavior of workers. Poland has historically been in a position of over-full employment, with labor shortage making it easy for workers to change jobs and hard for enterprises to find new workers when they were needed..$^{50}$ The labor situation has traditionally been further aggravated by widespread absenteeism and sick leave. Now, however, with workers afraid of job losses, sick leave has dropped sharply according to unpublished government surveys. Also, wage pressures have abated. In fact, enterprise wage bills on average have not reached the norms established under the tax-based wage policy in the first quarter of 1990, in sharp contrast with the dismal failure of the excess wage tax schemes in the mid-1980s.

Anecdotal evidence supports the survey data. A Polish-American reporter returning to Warsaw in March 1990 writes:

The change in people's attitude toward their work has been almost magical. Polish chefs, whom I had always classified as genocidal maniacs, suddenly started turning out palatable meals; perennially dirty Polish hospitals reported a surplus of candidates for low-paying cleaning jobs. In industry, sick leave decreased by 80 percent. I discovered that it became nearly impossible to lure even my most devoted friends out for a chat during their office hours: With the threat of unemployment looming, skipping work became too risky. ${ }^{51}$

Trade data for the first quarter of 1990 and surveys of enterprises' trade intentions conducted by the foreign trade organizations confirm that a process of adjustment is under way (see table 6). The trade balance on a shipments basis has produced a surplus of $\$ 778$ million over this period, larger than the $\$ 556$ million surplus for all of 1989 . By March the volume of exports was 18 percent higher than a year earlier, while the

50. See Rostowski (1989b).

51. Ziomecki, "Poland Discovers the Miracle." 
Table 6. Poland: Trade Developments, 1989-90

Millions of U.S. dollars

\begin{tabular}{lcccccr}
\hline & 1989 & & \multicolumn{4}{c}{1990} \\
\cline { 2 - 5 } \cline { 5 - 7 } & $\begin{array}{c}\text { Ist } \\
\text { quarter }\end{array}$ & & January & February & March & $\begin{array}{c}\text { 1st } \\
\text { quarter }\end{array}$ \\
\hline Trade balance & 301 & 13 & 244 & 521 & 778 \\
Exports & 1,958 & & 337 & 754 & 995 & 2,086 \\
Imports $^{\mathrm{a}}$ & 1,657 & & 323 & 510 & 474 & 1,308 \\
\hline
\end{tabular}

Source: Informacja Statystyczna (April 1990). Numbers may not total because of rounding. a. Excludes food aid.

volume of imports was down 35 percent. ${ }^{52}$ The sectoral trade performance shows that exports of certain products, such as agricultural products, electrical machinery, and chemical products, have risen sharply (see table 7). In other areas, however, exports have fallen, as in the case of the steel industry, where producers are being squeezed by the much higher costs of energy. Note that March exports reached nearly $\$ 1$ billion and relative to 12 months before show a stronger increase than does the average for the first quarter as a whole, suggesting a rising trend of exports. Of course, the information is still far too preliminary in 1990 to assess the medium-term impact of the reform measures.

On the import side, industry is purchasing large quantities of investment goods, presumably in response to the lifting of restrictions on such purchases and to relieve shortages of needed equipment and spare parts. Raw materials imports have fallen sharply, partly because of the domestic recession, but also partly to reduce existing inventories of inputs, which are excessive in light of the present demand conditions and the high real interest rates. ${ }^{53}$

The liberalized environment is also giving rise to the emergence of a domestic market, much of which remains informal, but which is apparently reducing the market power of some of Poland's most concentrated

52. These numbers probably overstate the trade surplus and understate imports. It is likely that with free access to foreign exchange in the parallel market, and at no premium relative to the official exchange rate, the incentive has risen to smuggle imports to evade duties. Therefore, some consumer imports are being financed through purchases in the kantor market and are not being registered in the official import data.

53. The sharp recorded decline in agricultural and processed food products is affected by two special factors. First, food aid, which was substantial in the first quarter, is not recorded as an import. Second, Poland experienced a record agricultural harvest in 1989, which has reduced its food import needs. 
Table 7. Poland: Non-CMEA Trade, 1990 $^{\mathrm{a}}$

Percent

\begin{tabular}{|c|c|c|c|}
\hline \multirow[b]{2}{*}{ Item } & \multirow{2}{*}{$\begin{array}{c}\text { Percent } \\
\text { distribution } \\
\text { by value, } \\
1990: 1^{\mathrm{b}}\end{array}$} & \multicolumn{2}{|c|}{ Percent changes by volume } \\
\hline & & $\begin{array}{c}1989: 1- \\
1990: 1\end{array}$ & $\begin{array}{c}\text { March } 1989- \\
\text { March } 1990\end{array}$ \\
\hline Exports & $100.0^{c}$ & 8.1 & 18.2 \\
\hline Electrical machinery & 23.5 & 18.6 & 38.1 \\
\hline Energy and fuel & 11.1 & -13.8 & -7.5 \\
\hline Metal products & 14.6 & -0.4 & 37.4 \\
\hline Chemical products & 12.5 & 18.5 & 6.7 \\
\hline Light industry & 6.4 & 0.9 & -10.4 \\
\hline Processed food & 13.0 & -4.0 & 7.4 \\
\hline Agricultural products & 7.6 & 60.7 & 21.8 \\
\hline Imports & $100.0^{c}$ & -19.5 & -34.7 \\
\hline Electrical machinery & 45.3 & 41.2 & 8.8 \\
\hline Energy and fuel & 6.5 & -31.8 & -33.5 \\
\hline Metal products & 7.4 & -29.8 & -56.2 \\
\hline Chemical products & 15.1 & -42.8 & -61.9 \\
\hline Light industry & 10.4 & 1.3 & -5.1 \\
\hline Processed food & 8.1 & -51.5 & -82.0 \\
\hline Agricultural products $^{\mathrm{d}}$ & 2.0 & -84.3 & -86.3 \\
\hline
\end{tabular}

Source: Informacja Statystyczna (April 1990, pp. 68-69).

a. Non-CMEA trade refers to trade in convertible currencies.

b. Values in U.S. dollars.

c. The breakdown of the distribution does not total 100 . The official sources do not provide data on the residual so we choose to exclude it from the table.

d. Excludes food aid.

sectors. The most notable example of this phenomenon, the food sector, illustrates the many dimensions of the change that is under way. Food processing had been one of the most concentrated sectors of the Polish economy. From the second week of January, farmers' markets cropped up all over Poland, including in the street in front of the Ministry of Finance, as farmers sought independent outlets for their produce. Farmers are processing food on the farms; independent, if illegal, butchers are opening up for business; and foreign food processors are visiting to inquire about the possibility of buying Polish meat and grains.

Market forces are also emerging rapidly in retail trade, where previously three enterprise chains had conducted over 90 percent of all retail business. Even the packaged and labeled products of the food processing industry can now be found in the informal markets, where they have been diverted to circumvent the huge retail enterprises.

An inevitable consequence of the stabilization and liberalization 
strategy is a decline in output. The only comprehensive data available on industrial activity show a decline of about 30 percent in production sold, meaning shipments from industry to distributors, wholesalers, and retailers, comparing the first quarter of 1990 with the same period a year earlier. Accounting for special factors and the output declines during the course of 1989, the Ministry of Finance estimates that production sold fell about 20 percent between February and the end of 1989 and then leveled off in March relative to February.

There are several reasons for the decline in output. Clearly, the restriction of aggregate demand has been severe, and output is giving way in response. In addition, a lengthy process of structural adjustment has been triggered by the relative price realignments. The transformation of the economy will require a massive resource reallocation, with delays between the freeing up of resources and their reabsorption elsewhere.

In addition, the extent of the decline in production is probably exaggerated. The emergence of new informal markets is substituting for production in the state sector. As an example, measured production in food processing has declined sharply since the beginning of the year, but it is obvious from the spread of farmers' markets that much of the decline is simply a shift to informal production not collected in the official data.

The dynamics of production will for many months be dominated by the process of dismantling the shortage economy. For example, an important reason for the decline in production sold is the initiation of a one-time inventory adjustment process. In January, the retail sector responded to the NBP policy of creating highly positive real interest rates by canceling deliveries from industry and running down stocks. For example, inventories of foodstuffs were reduced in January, with stocks of salt, barley, sugar, and flour falling by 27 percent, 37 percent, 54 percent, and 19 percent, respectively. While the interpretation of inventory data is plagued by difficulties with price deflation, retail inventories are reported to have fallen 63 percent in the first two months of 1990. Of course, a further important, but unmeasurable, factor in the slowdown in sales is the consumption by households of the hoards of goods that were commonplace in the shortage economy.

At the factory level, the slowdown in shipments has thus far led to an unwanted inventory accumulation, which bodes well for price and export prospects in the coming months but is also likely to contribute to the recession. The reason is that Poland's industry has protected itself from 
the shortage economy by holding huge stocks of primary and semiprocessed inventories. With the elimination of widespread shortage and the new, positive real interest rates, a sizable inventory reduction is likely to occur.

Adding to the difficulties of industry is the sluggishness of trade with the CMEA countries, particularly the Soviet Union. The volume of imports in nonconvertible currencies in the first quarter of 1990 was down 22 percent from a year earlier, mainly because of declines in imports of energy and equipment, both of which are vital for Poland's industry. Moreover, the volume of exports was down 3 percent in comparison with the same period a year earlier.

\section{The Remaining Agenda}

Poland faces enormous challenges in the months ahead. Taking the great leap required courage and wisdom, and now the far side of the abyss is proving to be slippery and steep. The primary objective in the near future will be to protect the gains in the areas of stabilization and liberalization. The second objective is to press onward in the areas that will determine Poland's long-term economic health: privatization, economic transformation, the liberalization of economic activity, and the reduction of external indebtedness. A third objective is to adopt adequate social safety net programs, so that the burden of reform is not unfairly distributed and does not undermine the social consensus for change.

The most difficult task in any stabilization is to stay on course. Already in Poland, the emergence of unemployment has evoked calls for reactivation and recommendations to loosen credit, expand public investment, and boost wages, as ways of halting the recession. And these calls for reactivation have arisen even though by April 1, the unemployment rate had not even reached 2 percent of the labor force. Reactivation, by a large expansion of credit at this stage, would undoubtedly jeopardize the stabilization program, as it has in the many Latin American programs where it has often been tried.

The main reason for the failure of reactivation is that stimulating aggregate demand in an open economy inevitably leads to a balance of payments crisis. ${ }^{54} \mathrm{~A}$ wage increase, for example, would hit the export

54. For a full discussion of this point, with evidence from Latin America, see Sachs (1989). 
sector the hardest, eroding competitiveness very quickly. Moreover, with little chance for a quick supply response, an expansion of demand would spill over into an increase in import demand. In Poland, a squeeze on export competitiveness along with a rise in import demand would drain international reserves and threaten a balance of payments crisis. The authorities would be left with the choice of abandoning the new, liberal trade regime or depreciating the exchange rate, thereby setting in motion a renewed wage-price-exchange rate spiral.

At present, Poland still suffers from a labor shortage, not a labor surplus, with unemployment less than 2 percent of the labor force. Thus there is little chance that an expansion of demand would lead to the absorption of unused resources, as in the crude, closed-economy Keynesian theory. In fact, a rise in real wages would squeeze enterprises, and probably lead to more, not less, unemployment. Moreover, it is premature to begin to resist increases in Poland's unemployment rate, as it remains well below any conceivable notion of a natural rate. Even to reach 5 percent of the labor force unemployed, Poland would have to see another 650,000 persons added to unemployment. Moreover, the scope and potential length of the transformation now under way could well result in unemployment rates that are temporarily higher than those experienced in healthy Western countries. It would not be surprising, therefore, if unemployment in Poland temporarily reached 10 percent of the labor force (1.8 million workers) as part of the adjustment process.

In the coming months, wage and exchange rate policy should be oriented to the objective of consolidating stability. At present, the wage environment is nearly ideal from the standpoint of maintaining stability: wage indexation has been ended, and, for the time being, wage pressure has abated under the specter of rising unemployment. Experience from Latin America demonstrates, however, that once the first stage of stabilization has lowered inflation to modest rates, wringing the remaining inflation from the system is usually complicated by the inevitable demands from labor for catch-up wage adjustments.

Catch-up adjustments are ostensibly granted to cushion workers from real wage declines. This reasoning most often proves fallacious, as such adjustments usually find their way into prices with little long-run effect on the real wage, in the meanwhile exacerbating unemployment and appreciating the real exchange rate. In the case of Poland, the catch-up would be doubly wrongheaded, since the initial conditions were of 
enormous shortage, so that actual real wage declines are far smaller than suggested by the data.

A different threat to stability often comes from the IMF, which pressures countries for devaluations to restore real exchange rate levels that existed at an arbitrary date of the stabilization program. The IMF has wrongly tried to target the real exchange rate by means of changes in the nominal exchange rate, a strategy that leads to rapid, if not explosive, inflation. ${ }^{55}$ The best chance for stability is to recognize that the nominal exchange rate is the fundamental "anchor" to the price level in an open economy the size of Poland. The prices should therefore adjust to the exchange rate, rather than vice versa.

\section{Privatization}

In addition to short-run policies aimed at consolidating stability, Poland must press ahead with structural transformation and other longerrun priorities. ${ }^{56}$ Most important, Poland must begin a rapid process of privatization of state firms, not only to assure efficient resource use in the future, but to prevent the collapse of the stabilization itself in the medium term. Experience around the world, plus the logic of the soft budget constraint, strongly suggests that it will be difficult to maintain the financial discipline of the state enterprises beyond the short run, especially if the state enterprise sector remains the dominant part of the economy. Eventually, wage pressures and lax investment decisions are likely to undermine the financial health of the state firms.

The rules and procedures governing privatization in Poland have not yet been put in place, with the delay reflecting the great political, economic, and administrative complexity of the task ahead. ${ }^{57}$ Prime Minister Margaret Thatcher, the world's leading advocate of privatization, has overseen the transfer of a few dozen state enterprises to the private sector in the past decade. Poland, however, has more than 7,800 candidates for privatization. The great conundrum is how to privatize a vast array of firms in a manner that is equitable, swift, politically viable, and likely to create an effective structure of corporate control.

55. In our opinion, an IMF policy in Yugoslavia during 1988-89 that pressed for nominal exchange rate adjustments to maintain a target real exchange rate was a key factor in the onset of the Yugoslav hyperinflation.

56. This section draws from Sachs (1990).

57. In view of this complexity we can touch only lightly upon the main issues involved. 
The complications of privatization begin with the fact that the ownership of the state enterprises in Poland (and the rest of Eastern Europe) is already politically contested. In many cases, workers wonder what the fuss is about, because of course they own the firms. And communist managers in many firms have simply assumed the right to trade, lease, merge, or even sell the enterprise assets, often for their own enrichment and to the fury of the public.

Privatization should begin by establishing that the central government owns the enterprises and has the exclusive power to engage in privatization. On grounds of social equity, the government should reject the workers' claims to full ownership of the enterprises, since the industrial work force represents only 30 percent of the labor force and 15 percent of the population. The workers' claims can, however, be partially recognized by giving them preferential access to a modest fraction of the shares of their enterprises and by giving the workers seats on the corporate board, as provided by company law in much of Western Europe. The government must also stop the managers from walking away with state property. For example, conflict-of-interest laws should be used to prevent managers from laundering state assets through dummy corporations that they create in the private sector.

The overriding aim of the privatization strategy should be to transform the enterprises into private corporations, with transferable ownership shares, rather than into alternatives such as worker self-managed firms or cooperatives. Worker-managed firms (except for small-scale, laborintensive operations) put workers at excessive risk and cut the firms off from the capital markets, because outside investors know that the workers can vote to pay themselves higher wages out of the company's profits.

The government must devise mechanisms that are rapid, but also transparent, for selling the enterprises, or transferring them free of charge, to the private sector. Shares can be sold to the public directly, transferred directly (for example, with a portion of each enterprise given to the workers or other stakeholders in the enterprise), or transferred to holding companies or mutual funds, which in turn would be sold or transferred to the public. Other arrangements, such as joint ventures and mergers with private firms, should also be used. As in many other countries, ranging from South Korea to Switzerland, Poland will almost surely regulate the participation of foreigners in the purchase of shares 
of state enterprises. To the extent that foreigners become owners, the firms should be sold for cash, or foreign equity, rather than in a swap for Poland's debt, because the government needs the cash and should seek more direct ways to achieve debt relief.

Unlike the British model of privatization, it is not urgent that 100 percent of the shares of an enterprise be sold or transferred. Some shares can remain with the Treasury. Several countries in Western Europe have shown that an acceptable level of efficiency and financial responsibility can be obtained in a mixed enterprise, part public and part private. Because the capacity of the government to sell a large number of enterprises might be limited, and because direct transfers of shares may be limited for budgetary or other reasons, the partial approach may allow for a greater number of firms to enter the process.

The standard method for privatization in the Western countries has been the public offering of shares of state enterprises. The process is time-consuming even in a country in which capital markets exist, and will prove to be even harder in Poland and the rest of Eastern Europe, given the fundamental difficulties of valuation and the absence of widespread secondary markets for trading in equities. There is also the problem that the financial assets of households are very limited. This last problem can be partly overcome if the government lends the public part of the money needed for the share purchases..$^{58}$

Many schemes have been suggested for the direct transfer of shares, as a way to speed the process of privatization and to overcome the limited financial wealth of the private sector. One proposal has been to issue to the general public, free of charge, a large number of vouchers that could then be used to bid for firms put up for auction. ${ }^{59}$ Another proposal has been to put the shares of enterprises in a few holding companies, with the shares of the holding companies in turn distributed

58. This lending could be made internally to the firm being privatized, or externally. In the former case, the government would sell a leveraged firm, in which the enterprise would owe part of its income stream to the government, in order to reduce the value of equity that the private sector must purchase out of its own resources. In the latter case, the government could allow banks to make equity loans to the public, or even to undertake purchases of shares on their own account, as in the case of German banks.

59. Such a procedure would be extremely complex logistically, and would not overcome the profound problems of valuation. Moreover, there would be little to assure that effective management for the enterprises would be developed, as the initial ownership of the firm could be extremely diffuse. 
to the public. There is concern, however, that such a process could actually lead to a recentralization of enormous economic power in the hands of a few institutions.

A third proposal has been to begin the privatization process by distributing part of the shares of each enterprise to various stakeholders in the enterprise, such as workers, state banks, and the local government in the region where the enterprise resides. The distribution of shares would be according to a common formula worked out in a political compromise. It seems clear to us that any transfer program that will win widespread political assent must indeed involve at least a partial transfer to stakeholders, as in this third proposal, rather than simply a transfer of ownership directly to households.

In view of the profound logistical and financial problems that would face the sale of thousands of enterprises through public offerings, it is likely that at least some direct transfer of shares will have to be envisaged. In such a case, it is important to remember that the Treasury now relies on the income stream of the enterprises as a major form of revenue, so that any transfer of shares must be offset by another form of revenue for the government. One possibility is that part of the annual income flow from the enterprise to the government would be converted from a "dividend" into a fixed bond. In effect, the government would sell a leveraged firm, and become a rentier rather than a capitalist.

In the end, privatization should probably be carried out by many means. The pace must be rapid, but not reckless, in order to achieve the basic objective of private ownership. But at the same time privatization should be carried out in a way that is fair, that raises the chances for effective management, that protects the Treasury, and that guards against the inadvertent creation of new concentrations of enormous political and economic power in the society.

\section{Other Structural Changes}

Many enterprises will remain in the state sector for a considerable time. For these firms, the government must oversee the work of enterprise restructuring, including horizontal and vertical divestitures, and must encourage new commercial and technical relations with Western firms. Massive management assistance will probably be needed to help enterprises cope with the new market environment and stay afloat in the 
absence of excess demand and cheap credits. Without such assistance, many enterprises will perform poorly, deepening Poland's recession unnecessarily, and some potentially viable enterprises may be forced into bankruptcy.

Poland must also promote its private sector. With state enterprise continuing to dominate the economy and enjoying favored access in the state-owned banking system, special attention must be given to ensure that private firms, especially small-scale firms, have a chance of gaining a foothold. It is probably worthwhile for the government to encourage the formation of financial institutions catering to the needs of small businesses. As the most recent data show, the private sector has so far been unable to tap credit from the state banks, holding just $\$ 120$ million of total loans from the entire banking system (a minuscule 2.7 percent of the total credit of the banking system). Promotion of the private sector must also include rapid progress in the privatization program now being designed.

Finally, Poland must press for a reduction of its external indebtedness. While cash flow relief from debt service has been forthcoming from the West, a deep and permanent reduction in the external debt burden is indispensable to Poland's economic long-term recovery. The successful transformation of the economy will require a climate in which large and sustained flows of private investment can be amassed. Poland's economy clearly holds the potential for highly favorable rates of return on new investment, especially for exports to Western Europe. Nonetheless, Poland's debt overhang makes the returns on these investments uncertain and frustrates the needed transformation. ${ }^{60}$

\section{Hopes and Fears for Long-term Change}

On purely economic grounds, there are profound reasons for optimism in the long term. In view of Poland's human capital, natural resources,

60. Owing to the prevalence of debt to official creditors, the reduction of the commercial bank debt burden under the Brady Plan would not be sufficient to provide a lasting resolution of Poland's debt problem. Poland will also need a reduction of official indebtedness. An important precedent for Poland, in light of the fact that West Germany is Poland's largest creditor, is the London Agreement of 1953, in which the United States and other creditor governments granted favorable repayment terms on German debt that substantially reduced the burden of that debt. 
physical capital, geographic proximity to Western Europe, and its prospects for increased economic and political harmonization with Western Europe, there is every reason to believe that Poland should be able to narrow decisively the gap in living standards with Western Europe. There is simply no reason why a country with Poland's resources, human and physical, should remain stuck at real income levels half, or below half, those of the poorest countries in Western Europe.

The gap in living standards should narrow as a direct result of institutional and political harmonization with Western Europe. We do not need to believe in the strong theorems of factor price equalization to recognize that an opening of free trade with Western Europe should increase the demand for Poland's skilled workers, who are now earning (at around $\$ 1$ an hour) about one-tenth to one-fifteenth of what comparably skilled workers earn just 500 miles to the west. The approach toward factor price equalization can arise both through trade and inflows of capital, as firms set up production operations in Poland for the purposes of exporting to the Western European markets.

And yet the happy picture of a steady growth in living standards at higher rates than in Western Europe, and so a steady narrowing of the income differential, while realistic enough economically, can still be frustrated politically. Few economists would doubt the picture for the eastern part of a unified Germany, since internal political problems are very unlikely to get in the way of a sharp rise in East German living standards (even aside from the direct equalization coming from labor mobility). But in Poland, and perhaps even more in other parts of Eastern Europe, the political barriers could remain severe.

The short-run costs of the move to a market economy may well lead to a rise of populism, protectionism, and a prolonged macroeconomic crisis. The decades-long agony of Argentina is proof enough that a country can get trapped in a seemingly endless political stalemate that blocks effective restructuring of the economy. Ironically, pressure to opt for an "easy" route can come from economists and policymakers who, naively judging the official data, believe that the short-run costs of reform are excessive and therefore support short-run melioratives that block long-term solutions.

The West too has a vital, and so far unfulfilled, role to play in seeing this process to its happier conclusion. With adequate short-run financial 
assistance and long-run debt relief for Poland, Hungary, and other heavily indebted countries in the region, the chances for a fresh start for these countries would be enormously magnified. A bold commitment of help from the West would help to spur a bold commitment to reform in the East. And the combination could help to fulfill the hopes of the democratic revolution of 1989 . 


\section{Comments and Discussion}

Stanley Fischer: David Lipton and Jeffrey Sachs have produced a fine paper, a work of persuasion that is nonetheless fully professional. They aim to persuade us that the first, stabilization, stage of the Polish program was well executed and is causing less pain than might appear from the reported data, for example that industrial output in the state-owned sector is down 30 percent. Despite its title, the paper provides less information on the second, structural transformation, phase of the program. That is both because less is known about what should be done and because at the time the paper was written, the stabilization was only three months old-and first things come first.

Because I agree with the paper's basic message, my comments will mainly supplement the analysis and arguments of the paper. Sequencing is the first issue to be faced in planning the reform process. For an economy facing hyperinflation, as Poland did at the end of 1989, the first step has to be macroeconomic stabilization. The structural measures come next, with transformation of the industrial structure, including ownership, the prime goal.

In the macroeconomic stabilization phase, it was necessary for the government to reduce its budget deficit, mainly by cutting subsidies, and for the central bank to plug gaps in the credit system-that is, to stop providing credit directly or indirectly to enterprises. Equivalently, enterprise budget constraints had to be hardened. Short-run success was achieved in both respects. But because the government has not yet had to confront the tough issues of unemployment and plant closings, we do not know how fully the provision of credit is under control.

Both the Yugoslav and Polish stabilizations of late 1989 suggest that it is possible to plug money-creating gaps in the credit system even in an 
economy with nonprivate firms and an underdeveloped banking system. All it takes is a tough government. It will take continued toughness to keep the gaps from reappearing and maintain low inflation.

The crucial element in the rapid reduction of inflation was the nominal exchange rate peg. It was also crucial that the initial exchange rate be heavily overdevalued relative to its long-run real equilibrium level. This the government achieved by setting the price of foreign exchange close to its black market level, which, being essentially an asset price reflecting the almost total absence of domestic stores of value, was high in relative purchasing power terms. The undervalued currency was essential both to provide incentives for exports and to leave room for the upward wage and price adjustments that were bound to take place in the first few months of the stabilization.

Lipton and Sachs seem to imply that the exchange rate should be kept fixed for a long period or forever. Commitment to this goal would be a mistake. Fixing the exchange rate helps bring inflation down rapidly, but the costs of overvaluation are so high that the government has to recognize that it may at some point want to change the exchange rateand it should therefore not stake its prestige on holding the exchange rate at its current level forever or even for a long time.

The paper emphasizes the convertibility of the currency. That is of course current account convertibility. The emphasis tends to obscure the daring nature of the Polish government's approach to trade reform. Whereas other reforming governments have typically removed quotas and reduced tariffs gradually, over periods of five to ten years, the Polish government freed up imports and reduced tariffs overnight.

The importance of this change cannot be overemphasized, for it answers the question of how a reforming and heavily distorted socialist economy can move to an appropriate price structure. With unrestricted current account convertibility - which requires an appropriate exchange rate and absence of trade restrictions-the country has the price structure that it needs to give the right signals for the reallocation of resources.

In this crucial respect, the Polish government made the most important structural change in the economy as part of the first, stabilization, phase of its adjustment program. This approach can be useful for all the East European economies. It would be less useful in the Soviet Union, which is much more closed and which by virtue of its size will continue to be more closed even if it reforms and opens up to external trade. 
The paper rightly emphasizes the need for tight monetary and fiscal policy. The mix matters too, for the real interest rate problem is already emerging. High real interest rates are inevitable in the early stages of a stabilization program. Ex ante real interest rates are also extremely difficult to estimate at the early stages, as point-to-point inflation rates differ radically from inflation rates calculated from monthly average price levels. Thus high real interest rates can and must be tolerated for some months. But high real interest rates maintained over a long period can bring economic distress even to firms that are only moderately indebted and in otherwise good shape. They also inhibit the investment that will be necessary as industry restructures. Continued fiscal tightness is essential if real interest rates are to be brought down gradually without reviving inflation.

Lipton and Sachs emphasize the need to deal with Poland's private and official debts. The budget and external accounts are in good shape only on the presumption that no interest will be paid. Poland is likely to get a Brady-type deal to reduce its debts with the commercial banks. But the bulk of its debt is official, and the question arises of whether the official sector will go beyond conventional Paris Club reschedulings to move to debt reduction. Unless Poland receives significant interest capitalization or debt reduction, the debt will hamstring Polish growth.

Macroeconomic stabilization is dramatic and reasonably well understood. By introducing current account convertibility, and by providing unemployment benefits, the government has included important elements of the next, structural, phase of reform in the stabilization phase. But stabilization is only the first-and much the easier-phase in the Polish structural adjustment program. The structural transformation issues, with industrial restructuring and privatization as the centerpiece, are less well understood and more important.

The Polish government has now to move ahead on industrial restructuring. This will undoubtedly be a lengthy process, but that is all the more reason to begin as soon as possible. Management of most firms will likely remain with current managers even as the property rights in those firms are clarified. For political reasons, and out of a simple concern for fairness, the government will probably decide to distribute ownership claims on existing firms as widely and equally as possible. A variety of schemes that mimic the operation of a stock market, and lead 
eventually to an actual stock market, is being explored and could be adopted.

Other reforms in the structural transformation process derive from the centrality of industrial restructuring. The design of the unemployment benefit scheme and other aspects of the social safety net have to be improved. Financial sector reform has to take place, perhaps in two stages, first to provide a simple and robust banking system by recapitalizing existing banks and improving their management, and later to introduce more sophisticated institutions. Housing sector reform is needed to permit more labor mobility. Increases in agricultural output are politically as well as economically essential if the people are to receive early benefits from the reforms.

Foreigners can make a big difference, through technical assistance and with financial resources. Foreign management consultants and management contracts for firms, especially in the banking system, can help upgrade management methods fast. Foreign direct investment brings in both foreign capital and management, but is likely to remain on a small scale until the ownership of existing firms is clarified and until prices can be established that will not leave the government vulnerable to the charge that it has sold national assets off too cheaply. The international financial institutions, the IMF and the World Bank, and later the European Bank for Reconstruction and Development, will provide money and expertise. And the Polish government welcomes both-to the extent that it is being overwhelmed by a deluge of foreign experts and delegations.

How optimistic should anyone be at this stage? Early in the paper, Lipton and Sachs compare Poland with Latin America. That comparison certainly comes to mind as one confronts a stabilization program from near-hyperinflation, based on a fixed exchange rate, in an economy that has to be fundamentally restructured. The dangers of backtracking on the stabilization are there. Indeed, those dangers account for the paper's puzzling optimistic bias, its apparent understatement of the costs of stabilization and overstatement of the benefits of eliminating excess demand and ending rationing. Why the optimism? Because the paper is also directed at a Polish audience: there is a debate going on in Poland, with many arguing that the time has come to ease up, that the program has brought nothing but hardship and promises nothing more. That 
argument is wrong. The program has brought a sharp reduction in inflation, and it has brought a start of restructuring. But much more has to be done; the supply response that is the ultimate goal of the reform will be slow and halting; and setbacks are inevitable in both the stabilization and restructuring processes.

Nonetheless, it is realistic to be optimistic for the longer term. The Polish government and society know what they want-a West European type of economy-and in this respect differ from the Latin American countries in which repeated stabilization attempts have failed. They are determined to open their economy to trade, foreign investment, and external expertise, and they have the world's largest market on their doorstep. The longer-term prospects for structural transformation are good.

Janos Kornai: The policy proposals David Lipton and Jeffrey Sachs advance in their paper will get no criticism here. Sachs and I discussed these issues several times, and we are in complete agreement on all basic principles. At this point, however, policy proposals have to be sold in Budapest, Prague, and Bucharest, not here. Therefore, this is the occasion to step aside from the role of adviser, educator, and preacher, and to attempt a prognosis.

We must be realistic. Even if we might hope for certain policies to be adopted and for certain outcomes to obtain, we must at the same time face their actual probabilities. Let me briefly discuss four such probabilities: the probability of there being a strong government, the probability of comprehensive reform, the probability of a new bourgeoisie emerging, and the probability of better management of the state-owned sector.

At this moment, Poland is fortunate to have a strong government enjoying popular support. But although the nation thus far remains united behind the Solidarity government, it is difficult to predict what will happen three or five years from now. East Germany's difficulties might be lessened, or might at least differ from those of other countries, given the special context of German reunification. But for the rest of Eastern Europe, strong governments with solid popular support are just one possibility. Just as likely are fragile government coalitions based on a fragmented political base. There is also a possibility that countries will become divided and that different social, ethnic, and ideological groups 
(for example, nationalist-xenophobic and outward-oriented) will become entangled in bitter struggles.

Lipton and Sachs refer to populist opposition to the measures adopted in Poland. In all countries, this is likely to be a very strong force. No matter what strategy of transition is chosen, there will have to be unpopular measures, and demagogues will have an easy time gathering political forces in order to oppose them.

This is the gloomy part of the political perspective. Immediately following the revolutions all East European countries knew a period of euphoria and new hopes associated with the idea of free elections. However, that will all be behind us after a while, and then comes the more difficult phase of actual policymaking.

In this situation, Western advisers, visitors, and governments should suggest and support social cohesion, a degree of national unity that can bear the painful changes that are needed. Even if the normal electoral process should lead to the government party or coalition being opposed by one or several opposition parties, it should be suggested to the opposition that it not be destructive or obstructionist during the period of transition; otherwise, all changes will fail.

The political background is of crucial importance for the comprehensive policy discussed in Lipton and Sachs's paper and known variously as "one stroke," "big bang," or-as in my own book, The Road to a Free Economy - "surgery," a major operation on a patient involving a whole package of measures.

If the government is committed, strong, and enjoys a solid national backing, there is a good chance that such comprehensive reforms and measures, painful but needed, will come to pass. But if the system is very fragile and the opposition powerful, populist, and kindled by demagoguery, then it will become politically unfeasible to implement a comprehensive reform surgery.

The considered opinion of wise economists as to what is bettergradualism or particular kinds of sequencing-will not be decisive. What will be decisive is the natural way of making political decisions, and that means putting difficult and painful decisions off tor a while. These political factors mean that there is a significant probability for permanent postponement and partial solutions that will be bad for the country involved. This, again, is one of the gloomy prospects. 
The Hungarian experience clearly shows the dangers and negative effects of partial changes. Hungary has already experienced 20 years of muddling through with such partial changes. For instance, prices were never more than partially liberalized. Yet a sequence of partial price liberalization measures will never result in a rational price system, only in the fueling of inflation. Through a price-wage-cost spiral, rising prices in one segment of the economy induce cost and price increases in the others. These then call for additional subsidies for the firms and even whole sectors that were hurt by the cost-push effects. Under these circumstances, partial price increases draw other prices behind them, and the initial effect of more rational relative prices is washed away by the rise in the remainder of prices. The final outcome is the continuation of price distortions at an ever higher general price level.

In addition, partial liberalization of prices unaccompanied by wage controls may also have very bad inflationary effects. Finally, partial convertibility without hard budget constraints on the firm and without tight monetary control may lead to a rush for foreign exchange, as state enterprises want to get as much hard currency as possible without paying for the consequences.

In conclusion, there is a high probability of protracted, half-hearted partial reforms that may cause much harm. Western economists visiting East European countries for any reason should encourage bold and comprehensive reforms, knowing that there will in any event be a strong natural resistance against them for political reasons.

The third issue is the potential for privatization. The problem of privatization should be looked upon as a problem of social transformation and therefore necessarily as an evolutionary process. It was possible to liquidate the kulaks in half a year, but it is impossible to recreate rich farmers as quickly. It cannot be accomplished in a "big bang."

The question then is where to put the emphasis? I would put it on the creation of a new middle class of small- and medium-sized businesses, on a process of embourgeoisement that develops genuine Schumpeterian entrepreneurs with strong incentives for innovation and for the development of their property. There are many people all over Eastern Europe who are willing to engage in private business and are, it would seem, able to do so. They need encouragement and the removal of remaining legal barriers to their activity-a change that amounts to the destruction 
of the bureaucratic barriers characteristic of the old regime. In addition, they need credit to get them going, that is, initial capital.

Indeed, one of the shocking numbers in Lipton and Sachs's paper is the amount of credit given to the private sector. It is disastrously low, 2.7 percent of the total credit supplied by the banking system. This fact alone shows that something serious is missing, and that policymakers and economists focus in a one-sided manner on the problems of the large state-owned enterprises. They are, of course, a very important part of the situation. Yet people may be paying too little attention to the encouragement of a new social structure through social transformation.

This social transformation took centuries for those parts of the world, including Eastern Europe, that went through this process. Right now, we are once more starting almost from scratch, at least in the Soviet Union. Hungary and Poland may be somewhat better off because the informal private sector may have been more developed there than in some parts of the Soviet Union. For us the process will probably not take centuries but, it is to be hoped, only years. Yet much more attention should be paid to speeding it up. International organizations tend to have a one-sided interest in the corporate sector and to neglect genuine, private, visible entrepreneurs, and helping them get started.

Finally, a few comments concerning the state-owned sector. There may be no good solution on how to manage the state-owned sector. Economists in Eastern Europe need to be convinced of this fact. We witness a very strange revival of market socialist ideas in Eastern Europe. When the communist party was still in power, the so-called reform communists suggested running the economy on the basis of a combination of public ownership with market coordination. This was the central idea of what one may call the communist phase of market socialism. In the Soviet Union, official policy still adheres to this goal.

The experience of Hungary, Yugoslavia, Poland under Rakowski, and Gorbachev's perestroika all show that this goal is doomed to failure. It will also fail in China, where the successful part of the reforms is the privatization of agriculture and not the market socialization of stateowned enterprises in the manufacturing sector.

One has a strange feeling of déjà vu when people who are noncommunists or even anticommunists get into power and think that they can manage the state sector in the right way. They think that because they 
are not communists they will be able to run their central bank, their Ministry of Finance, and their state-owned enterprises efficiently. They are sure to fail. In this respect, the present Polish experience is not conclusive because state-owned enterprises are being run under a state of emergency, based on a hard budget constraint enforced through extremely tight credit supplies. The genuine test of insolvent stateowned firms going out of business and being liquidated is not yet furnished. Maybe Jeffrey Sachs and David Lipton already know of instances when a state-owned business has been finally closed down, but certainly it is not being done on a mass scale yet.

I was told that one should never say in the United States that a problem has no solution, yet there are certain problems that have no solution, one of them being the efficient operation of a large state-owned sector. Of course, state-owned firms can be efficient if they are a very minor part of the economy and surrounded by a large private sector. Perhaps the Swiss railroads are running well, but even about this it may perhaps be better to ask the Swiss.

The second insoluble problem is that it is impossible to privatize in a "big bang." What to conclude? That for a long time, inevitably, a large part of the economy, in particular the gradually shrinking, but still rather large state-owned sector, will run inefficiently. This fact of life must be taken into account. If everybody is knowledgeable and works together, then this period may be relatively short. But should these countries be less fortunate and more divided politically, then the period of inefficiency may be very protracted. It will be a relatively painful period of gradual privatization and of stop-and-go tightening or loosening of policies visà-vis the state-owned sector. And while passive observation of what goes on would certainly be wrong, it seems that however energetically we may act, we cannot expect a quick, overnight solution of our problems.

\section{General Discussion}

Several panelists suggested that popular resistance to markets is likely to emerge and worsen the prospect for successful reform in Eastern Europe. Thomas Juster observed that even in the United States markets are not very popular with consumers. He cited evidence that people feel 
that price increases resulting from scarcity, as opposed to increased cost, are not fair. Furthermore, serious inflation makes people perceive themselves to be worse off, even without a decline in their real wage. Both phenomena are likely to be prominent during the introduction of a market economy. Juster was particularly skeptical that consumers would be content with rising prices and declining measured real wages, compensated only by a decline in queuing time. In a similar vein, William Poole noted that as the economy of Poland is liberalized, successful entrepreneurs will earn high incomes. He suspected that such incomes and the accumulation of wealth by a small portion of the population would be unpopular.

Jeffrey Sachs cautioned against overstating the popular resentment toward price increases. When food prices in Poland jumped in January, the public's anger was directed at the communist monopoly on food distribution. In February, the government was finally able to break up the monopoly, a step they had been unable to take before. Sachs felt that realistic, explainable, rational steps could be taken at the beginning of the reform process without fear of public rejection.

The de facto control of Polish firms by workers led Charles Schultze to doubt that decreases in employment would be the primary effect of a fall in demand. Rather, given the monopoly power enjoyed by many of these firms, the main effect would be a rise in prices to make up the lost revenue, with workers left underemployed. Sachs agreed that enterprises have been essentially labor-managed since the imposition of martial law. It has become politically impossible to install professional managers with the power to make employment and investment decisions. He predicted that the first real test of the reform process will be whether the Poles actually close enterprises. He emphasized that fears of unemployment are exaggerated. Unemployment started out very low, and the real question is whether the unemployment rate will be allowed to rise enough. As firms come under pressure, they each appeal for a bailout to preserve their employment level.

Some panelists were more optimistic. Georges de Menil seconded the authors' point that the Polish situation was better characterized as liberation from an administration of occupation than as an internal political revolution. He added that the Polish Catholic Church was a strong unifying factor. For these reasons, the Polish situation was entirely different from that of the Soviet Union. 
Panelists offered numerous suggestions about the pace and technique of reform. Charles Holt, noting the severe budget problems, suggested gradually phasing in the safety net as government support for industries is phased out. Joseph Stiglitz was concerned that entrepreneurs would hesitate to make investments if they feared that reforms would be reversed by later administrations. He found some lessons in Margaret Thatcher's privatization of certain British enterprises, which appears irreversible. William Poole emphasized that if privatization did not proceed with a sense of urgency, it would take much too long, allowing problems to be created and opportunities to be lost. He argued that the government should be prepared to sell at a discount to get the enterprises into the private sector quickly. Stiglitz, on the other hand, argued against a "giveaway," stressing the importance of giving proper signals about profitability of firms. Peter Kenen also expressed reservations about rapid privatization on the grounds that worrying too much about efficiency would add political roadblocks to more urgent reform. Recognizing that insufficient private wealth is one possible obstacle to privatization, Franco Modigliani suggested the state sell off only a fraction of an enterprise but leave all management to ownership.

William Branson justified government loans to finance consumption during the transition to a market economy on the grounds that reforms will be costly for the current generation and will benefit later generations.

There was general agreement that opening the economy to the rest of the world is an important ingredient of successful reform. A number of comments were made about the impact of trade and capital mobility. John Williamson agreed that the desire to "import" a relative price structure provided an extra argument in favor of a fixed nominal exchange rate, but argued that one still needed to ask the standard questions about whether there would be sufficient internal price flexibility in the medium term to avoid overvaluation developing through inflation inertia. Conversely, he pointed out that an undervalued exchange rate would result in upward pressure on prices. William Branson pointed out that the extent to which the Polish and world financial markets were interconnected would have an important bearing upon the persistence of high real interest rates in Poland, and that therefore the way the capital account exchange rate was handled could be crucial to reform.

Stiglitz questioned whether the larger economies of the Soviet Union and China would be able to benefit from foreign competition and foreign 
prices. Kenen replied that even in the continental Soviet economy, opening the foreign sector may be the most effective way to move quickly on price reform and liberalization. William Brainard observed that although introducing world competition was desirable, world prices might not be the best guide for domestic allocation of resources. For example, world prices include capital charges that are not likely to be correct for the current Polish economy.

Two questions arose about data. Juster called into question the view that past data on Eastern European economies have overstated growth rates. For the growth rates to be incorrect, he reasoned, it is not enough that the data be biased; they must be becoming more biased. Brainard was curious about what had become of the revenue induced by the 30 percent decline in real wages. Sachs replied that in the past, black market prices were much higher than official prices and now they are lower than the official prices; thus, transaction prices have risen much less than official prices. He also indicated that the additional revenue has gone toward a reduction in the inflation tax and to some extent toward increased profits within the firms. 


\section{References}

Alton, Thad P. 1989. “East European GNP's, Domestic Final Uses of Gross Product, Rates of Growth, and International Comparisons.' In Pressures for Reform in East European Economies, vol. 1. Washington: Joint Economic Committee, Congress of the United States.

Balcerowicz, Leszek. 1989. "Polish Economic Reform, 1981-88: An Overview." In Economic Reforms in the European Centrally Planned Economies. New York: United Nations, Economic Commission for Europe.

Ehrlich, Éva. 1985. "The Size Structure of Manufacturing Establishments and Enterprises: An International Comparison." Journal of Comparative Economics 9: 267-95.

Fallenbuchl, Zbigniew M. 1985. National Income Statistics for Poland, 19701980. Staff Working Paper 776. Washington: World Bank.

- 1989. "Poland: The Anatomy of Stagnation." In Pressures for Reform in East European Economies, vol. 2. Washington: Joint Economic Committee, Congress of the United States.

Fink, Gerhard, and Peter Havlik. 1989. "Alternative Measures of Growth and Development Levels: Comparisons and Assessment." In Pressures for Reform in East European Economies, vol. 1. Washington: Joint Economic Committee, Congress of the United States.

Grosfeld, Irena. 1987. "Modeling Planners' Investment Behavior: Poland, 1956-1981." Journal of Comparative Economics 11: 180-91.

Informacja Statystyczna. 1989 and 1990, various issues. Statistical Information Monthly. Warsaw: Central Statistical Office.

International Monetary Fund. Various years. International Financial Statistics. Washington.

Kaminski, Bartlomiej. 1989. "The Economic System and Forms of Government Controls in Poland in the 1980s." In Pressures for Reform in East European Economies, vol. 2. Washington: Joint Economic Committee, Congress of the United States.

Kornai, Janos. 1989. "The Affinity between Ownership and Coordination Mechanisms, the Common Experience of Reform in Socialist Countries.", Round Table Conference on Market Forces in Planned Economies, Moscow.

- 1980. Economics of Shortage. Amsterdam: North-Holland.

. 1982. Growth, Shortage, and Efficiency: A Macrodynamic Model of the Socialist Economy. Oxford: Basil Blackwell.

- 1986. "The Hungarian Reform Process: Visions, Hopes, and Reality.", Journal of Economic Literature 24: 1687-1737.

- 1990. The Road to a Free Economy, Shifting from a Socialist System: The Example of Hungary. New York: W. W. Norton and Company.

Kouba, Karol. 1989. "A Predicament of Systematic Changes: Supply and Demand Pricing.' Second U.S.-Czechoslovak Roundtable on Economic and Political Relations. Prague, Czechoslovakia. 
McDonald, Kevin. 1990. "Resources Needed for Restructuring Selected Polish

Companies.' McDonald and Company, Newton, Mass. (February).

OECD Labour Force Statistics, 1967-1987. 1989. Paris.

OECD National Accounts, 1975-1987. 1989. Paris.

Rocznik Statystyczny. Various issues. Statistical Yearbook. Warsaw: Central Statistical Office.

Rocznik Statystyczny Przemyslu. Various issues. Statistical Yearbook of Industry. Warsaw: Central Statistical Office.

Rostowski, Jacek. 1989a. "The Decay of Socialism and the Growth of Private Enterprise in Poland.' Soviet Studies 41 (no. 2): 194-214.

- 1989b. "Market Socialism Is Not Enough: Inflation vs. Employment in Reformed Communist Economies." Communist Economies 1 (no. 3).

Roubini, Nouriel, and Jeffrey D. Sachs. 1989. "Political and Economic Determinants of Budget Deficits in the Industrial Democracies.' European Economic Review 33: 903-38.

Sachs, Jeffrey. 1990. "Eastern Europe's Economies.' Economist, January 13, 1990.

- 1989. "Social Conflict and Populist Policies in Latin America." Working Paper 2897. Cambridge, Mass.: National Bureau of Economic Research.

United Nations, Economic Commission for Europe. Various years. Economic Survey of Europe. New York.

Vacic, Aleksandar M. 1989. "Current and Prospective Economic Reforms." In Economic Reforms in the European Centrally Planned Economies. New York: United Nations, Economic Commission for Europe.

Weitzman, Martin L. 1990. "Price Distortion and Shortage Deformation: Or What Happened to the Soap?" Cambridge: Harvard University (January).

$\rightarrow$ Winiecki, Jan. 1986a. "Central Planning and Export Orientation." Eastern European Economics 24 (no. 4): 67-89.

$\longrightarrow \rightarrow$ 1986b. "Sources and Symptoms of Inflation in the Planned Economy.", Eastern European Economics 24 (no. 3): 53-73.

- 1986c. "Soviet-Type Economies: Considerations for the Future." Soviet Studies 38 (no. 4): 543-61.

World Bank. 1989a. Social Indicators of Development. Washington. 1989b. "Malaysia: Matching Risks and Rewards in a Mixed Economy.", New York.

Wyzanski, Pawel. 1989. "The Foreign Currencies Black Market." Ph.D. dissertation, Warsaw University. 